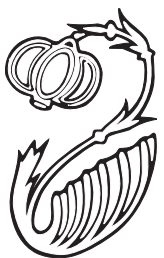

\title{
Justice, Geography and Empire in Aeschylus' Eumenides
}

\begin{abstract}
This paper argues that Aeschylus' Eumenides presents a coherent geography that, when associated with the play's judicial proceedings, forms the basis of an imperial ideology. The geography of Eumenides constitutes a form of mapping, and mapping is associated with imperial power. The significance of this mapping becomes clear when linked to fifth-century Athens' growing judicial imperialism. The creation of the court in Eumenides, in the view of most scholars, refers only to Ephialtes' reforms of 462 BC. But in the larger context, Athenian courts in the mid-fifth century are a form of imperial control. When geographically specific jurisdiction combines with new courts, it supports and even creates a developing imperial ideology. Moreover, the figure of Athena and the role she gives the Athenian jury emphasizes a passionate pro-Athenian nationalism, a nationalism that the text connects to Athens' geographic and judicial superiority.

This imperial ideology did not spring from Aeschylus' imagination fully formed; it reflects a trend in Athens of promoting her own cultural superiority. This sense of cultural superiority in fact disguises the realities of Athens' developing power and increasingly harsh subjection of her former allies.
\end{abstract}

"It is difficult ... to show the involvements of culture with expanding empires, to make observations about art that preserve its unique endowments and at the same time map its affiliations, but, I submit, we must attempt this, and set the art in the global, earthly context. Territory and possessions are at stake, geography and power."

\section{Edward Saïd, Culture and Imperialism}

As the title suggests, the aim of this piece is to discuss the concepts of justice, geography and imperialism in Aeschylus' Eumenides. What I intend to show is

I would like to acknowledge the many individuals who helped me get this article together, especially June Allison, who encouraged me from the beginning and who read innumerable early drafts. Also, thanks to Mark Griffith and the anonymous referees at Classical Antiquity for their very thorough and insightful comments. I am indebted to you all.

Classical Antiquity. Vol. 25, Issue 1, pp. 35-72. ISSN 0278-6656(p); 1067-8344 (e).

Copyright ( $\odot 2006$ by The Regents of the University of California. All rights reserved. Please direct all requests for permission to photocopy or reproduce article content through the University of California Press's Rights and Permissions website at www.ucpress.edu/journals/rights.htm. 
that there is a coherent geography within the play that is interconnected to the legal proceedings described and that these two elements, justice and geography, form the basis for an imperial ideology. Aeschylus may not intend to support the imperial ideology; he nonetheless reflects Athens' promotion of her cultural superiority in the realm of justice, and it is this idea of justice that Athens uses to disguise and justify its growing imperial power.

Previous discussions of Eumenides by scholars have addressed a few of the geographic references in relation to Athenian military/imperial activities in the early to mid-fifth century. These references have often been lumped together with the other "political" elements of the play and, especially since Dover dismissed many of them long ago as irrelevant, they are generally underappreciated in analyses. Noel Robertson labels much of Aeschylus' geography, both in Eumenides and in other plays such as Persae as "geography extravaganzas." But these passages are not necessarily ornamental. On the contrary, the geographic locations mentioned in Eumenides, I contend, constitute a form of mapping. Mapping and geography are always associated with power, or more specifically, imperial power. ${ }^{1}$ Mapping was-and is - a way of making something unknown known, and the one possessing this knowledge gains control over the mapped space. Just as the map of Cleomenes (Hdt. 5.49.5-8) and Agrippa's map of the world were clearly used to express spheres of control, so too is Aeschylean mapping here defining the physical space of Athens' hegemony.

The region defined by the geography of the text is not necessarily significant in and of itself, but rather becomes so when one considers how Athens wished to define the power it exerted within the space. Aeschylus' text proposes a form of control which I call judicial imperialism. For it is institutionalized justice, not abstracted, that finds itself the focus of the third play of his trilogy. And it is specifically Athenian justice that is put forth as a mechanism of control for the defined region. This is a form of imperialism that, because of the political nature of the event at which the play was performed, registers as a part of an imperial ideology. ${ }^{2}$ Eumenides will support and even create this imperial ideology because the geographic and judicial superiority of Athens suggested by the text is linked to a passionate pro-Athenian nationalism that is emphasized both by the figure of Athena within the play and by the role she gives the Athenian jury. ${ }^{3}$

1. As Godlewska and Smith 1994: 4 put it, "historically, nothing characterizes geography so tellingly as its close contacts with those either seeking or holding territorial power." And, as Rehm 2002: 94 recently has commented concerning Eumenides, "given Athenian extraterritorial activity in 459, concerns with its Empire do not seem far-fetched." This is, however, the extent of the comment. For thorough and enlightening discussions of mapping in the ancient world, cf. Romm 1992 and Nicolet 1991.

2. For a complete study of the imperial/civic context of Athenian tragedy, cf. Goldhill 1990 and 2000a.

3. Godlewska 1994: 33-35 suggests a similar relationship between the geography and imperial ideology of Revolutionary and Napoleonic France. This "newly fervent nationalism" was tied to the overthrow of the monarchy and the creation of the Republic. Its aim was to liberate and 
Giving such attention to the geography of Aeschylus' Eumenides is not an obvious decision for a scholar. In fact, as a brief overview of previous scholars' views on the geography in Eumenides will demonstrate, not many have considered it significant. However, a look at the geographical concerns of Aeschylus' other plays demonstrates that either Aeschylus himself was interested in geography or a general cultural concern was manifesting itself through his drama.

In a recent APA paper, ${ }^{4}$ Peter Rose suggested that it might be in scholars' best interests to open up a wider discussion of the value of geography in Aeschylus' texts. Geography has, he writes, been examined but only insofar as it pertains to the creation of a Greek/Persian dichotomy. But geography, a form of knowledge, ultimately always serves power, as he reminds us with reference to both Foucault and Saïd. It is exactly this contention that is at the heart of this article: geography is rarely just incidental or ornamental.

Aeschylus' earliest extant play, Persae, is very interested in geography and its relationship to power. The geographic references made in Persae 864-906 are no mere "geography extravaganza." As Rosenbloom has pointed out, the play makes clear one major truth at the time of the Persae's production: these lands were all once part of the Persian Empire and the Athenians had acquired them as a result of their victories. ${ }^{5}$ And, as Meier writes, "with what pride must the Athenians have listened to the long catalogue of Greek cities which had been conquered by Darius only to be liberated by Athens!"6 These are neither random nor gratuitous references.

Concerning Agamemnon, Rose concludes that Clytemnestra's recounting the journey of the fire-signal reflected the geographic dominance of mythical Argos over the places named. ${ }^{7}$ The journey of Io in Prometheus Bound ${ }^{8}$ has also been considered "a mythical charter for the far-flung dominion of her many descendants."

civilize those outside of France. It was a "collective illusion closely tied to a new nationalism which argued the coherence and superiority of the French social and political order...." I will argue below that this same superiority is felt by Athenians concerning their legal system. Similarly, Anderson 2003: 123-211 argues for the emergence of such a coherent national identity and patriotism accompanying the democratic reforms of Cleisthenes in 508/7 BC. Anderson sees the reforms as more than just constitutional reforms but rather as a fully systemic, cultural transformation of the Athenian mentality. Central to the rise of Athens in the decades between the reforms and the Persian invasion at Marathon was the creation of unified national character, an "imagined community" that bound all Athenians together.

4. Rose 2003. All references are to a copy of the paper kindly provided to me by Professor Rose. It is my understanding that, at this time, he has no intentions of publishing the contents.

5. Rosenbloom 1995: 93.

6. Meier 1993: 70.

7. Rose 2003: “... Clytemnestra's triumphant tone reflects her sense of power over all the places that make such a system feasible, so too the Athenian audience hears a dazzling confirmation of their own domination of so many places."

8. I will not involve myself here in the debate over Aeschylean authorship. For arguments for Aeschylean authorship, cf. Herington 1988; and S. Saïd 1985: esp. 9-15. For arguments against, cf. Griffith 1977 and West 1990: 51-72.

9. White 2000: 118. 
And Pelasgus' speech at Supplices 249-73 is especially interesting. The geographical extent of Argos' dominion begins in the Strymon valley and extends to Thessaly and Epirus. If we understand Argos here as an analog for Athens, then we could argue for the same imperialist undertones in the geography of Supplices as I will argue for in Eumenides. If this is the case, then the shift from Delian League to Athenian empire could be understood as accepted fact by 463 BC. However, the regions defined are, for the most part, in the reaches of northern Greece that were, practically speaking, outside of the Athens' attested or even desired realm of influence. The distinction made at 277-90 between Greek and barbarian, however, seems to be more to the point. That said, the negative space created by Pelasgus' two speeches at 249-73 and 277-90 leaves a region that could represent an Athenian hegemonic sphere. Thus, in a number of plays attributed to Aeschylus, there is an emphasis on geography and the geography seems to be linked ideologically to the re-conquest of Greek lands by the Greeks at the expense of Persia. Eumenides, I will argue, does just this, but also goes further by linking such conquest with a purely Athenian ideology of freedom granted and guaranteed through the courts.

The emphasis on geography is not the only aspect of this argument that is not obvious. My contention that Aeschylus' text supports a pro-imperialist ideology is not universally accepted, nor is the Empire even commonly considered a potential influence on Aeschylus. David Rosenbloom suggests that "in the Oresteia and Persians Aeschylus presents the fearful vision of poleis ruined by the seduction of sea power and the forms of military and political domination it makes possible." 10 Rosenbloom further contends that Aeschylean tragedy calls into question the naval empire of the Athenians: "The vision of his drama implies that naval hegemony, the forms of war built upon it, the power derived from it, and most of all, the delusions of conquest and justice it supports, can be deleterious to the polis." 11 Rosenbloom bases this conclusion on his contention that Aeschylean tragedy, especially the Persae and Oresteia reflect what he calls an "ideology of freedom." This "ideology of freedom," he claims, is inherent in the tragic genre just as it is in historiography and consists of two primary stages: "the conquest of hubris and the violent reversal of domination driven by a demand for freedom." ${ }^{12}$ Rosenbloom goes on to suggest that this ideology is subverted in the tragedies of Aeschylus because Aeschylus recognizes that "freedom is a precondition for domination.... Domination is subverted and hubris is conquered; the liberated gain power." 13

He supports this conclusion by examining the position of Agamemnon as a strategos in the Oresteia. Agamemnon's acceptance of Clytemnestra's calling

10. Rosenbloom 1995: 98. Rosenbloom is not alone in this contention of the anti-imperialist nature of Aeschylus' drama. Cf. Melchinger 1979.

11. Rosenbloom 1995: 95. For a different understanding of naval power in fifth-century Athens, cf. Raaflaub 1990 and 1998.

12. Rosenbloom 1995: 92

13. Rosenbloom 1995: 92. 
him a city-sacker and persuading him to walk on the carpet as a "barbarian" king would do creates, Rosenbloom suggests, an anxiety about Attic traditions and cultural exchange. The fleet may bring salvation on the one hand, but it turns the victor (Agamemnon) into an eastern potentate (the vanquished) on the other.

But this dynamic, I will demonstrate, does not hold true by the time we move from Agamemnon to Eumenides. In Eumenides, all the power that was concentrated in Agamemnon is given over to Athena and the Athenian citizenjury. They become the healers of a broken house of Atreus. Where Agamemnon fails, Athena and Athens succeed. Thus the trilogy does not necessarily question the power Athens has acquired through its navy.

To help explain the apparent contradiction noticed by Rosenbloom within the plays, I appeal, in addition to an ideology of freedom, to an ideology of power. Raaflaub links an ideology of power with the concept of "the greatest and freest city" found in Pericles' and other Athenians' speeches in Thucydides. The polis, he suggests, was convinced that it could only maintain its liberty by being powerful. Being powerful meant ruling others. ${ }^{14}$ This ideology of power finds itself manifested in the growing Athenian Empire. But the two forces must be examined together since it is only through recognition of their interaction and deep connectedness that one finds an understanding of Aeschylus' tragic vision.

It must be stated here that this discussion will not involve deciding whether or not Aeschylus was a left-wing radical or a right-wing reactionary. ${ }^{15}$ Nor will I answer the long persistent question of whether Aeschylus supported Themistocles, Pericles, Ephialtes or Cimon. ${ }^{16}$ Nor will I involve myself in the debate over the nature of the reforms of the Areopagus. For within the framework of a play of ideologies, the subject of authorial intent becomes a moot point. ${ }^{17}$ Always

14. Raaflaub 1994: 117-18, 124. Cartledge 1998: 56 is also concerned with the problem of the relationship between freedom and power in fifth-century Athens. He understands freedom as being an "archetypal" and "architectonic" value for the Athenians and yet in conflict with an ideology of power which dictates that being dominant is manly and that conquest is inherently good.

15. For conservative, cf. Rhodes 1981: 261-63; Calder 1981; Cole 1977: 99-111; Conacher 1987: esp. 195-206; and Rosenbloom 1995-though Rosenbloom does not directly state this view, it is implied in his arguments. For Aeschylus as a progressive, cf. Dover 1957; Dodds 1973; Podlecki 1973: 49; Sommerstein 1996: esp. ch. 12. Page 1957: xi writes on the subject, "The Eumenides leaves little room for doubt that its author counted himself among the progressives." Both Goldhill 1992: 89-92 and Pelling 2000: 164-88 like to see Aeschylus as breaking partisan boundaries. He is, they both suggest, looking to "national" well-being in his hope for a resolution to stasis. Griffith 1995: 62-129 would also like to see the text bridging partisan lines. He argues that Aeschylus is in fact reconciling both groups by both praising the democracy and its institutions and giving a crucial role to the traditional aristocracy in the government. For a good overview, cf. Braun 1998 whose primary focus is establishing what the actual reforms and function of the Areopagus were. He concludes that Aeschylus was a democrat who saw the Solonian constitution as an ideal democracy and was thus supporting democracy while not supporting radical democracy.

16. This type of question was addressed by Ehrenberg 1954. Cf. Braun 1998: 60-80.

17. This point has been emphasized by Meier 1993: 115 and, citing Meier, Goldhill 2000b: 69. S. Saïd 1998: 278-80 also expresses misgivings with looking for such topical references as authorial support for a specific political institution. 
there are forces working upon and through an author (and audience) that are beyond the control of the author. In other words, intention gets subsumed beneath and incorporated within the framework of the dominant ideologies. Culture is, therefore, simultaneously always creating, questioning and supporting ideology in spite of the author. And, as Rose again reminds us, while we may discern within the plays of Aeschylus a more narrow ideological intent on the part of an author, such as the creation of Greek/barbarian dichotomies and a fascination on the part of the author for foreign places, it does not mean that an undercurrent, which either questions or supports the imperial project and the more broad ideology associated with it, is not unintentionally present as well.

The inability to recover intent does not mean that a historicist approach cannot be applied to the reading of tragedy. Instead, we must turn to the very forces that participate in the creation of political climate in Athens. In the case of Athens, these forces are the simultaneous spread of empire and the development of the Athenian judicial system both as a tool of the empire and as a medium for creating a specific cultural identity for Athenians. We must envision tragedy as a part of the total matrix of cultural production on a par with other forms of art (i.e. architecture, sculpture, etc.) and with political documents such as inscriptions, speeches and histories. The argument here, then, will be two-fold. I will reopen the discussion of different political issues within Eumenides considered by previous scholars but examine them as elements of and producers of empire rather than as pertaining to internal political rivalries. At the same time, I will demonstrate how the geography of Aeschylus' text brings coherence to these seemingly scattered and "internal" political references by linking them all to the development of Athens' empire through the spread of a newly conceived Athenian identity linked with judicial institutions.

The political issues addressed in Eumenides have generally been identified as follows: (1) the Argive alliance (289-91, 669-73, 762-74); (2) the reforms of the Council of the Areopagus by Ephialtes (and Pericles) in 462 BC (681-710); (3) the disputed possession of Sigeum (397-402); and (4) movements of the fleet in Egypt (292-97). ${ }^{18}$ My discussion of these issues will be broken into two sections. First, I will address the possible geographic references to the Troad (Sigeum) and Egypt along with other locations that appear in those same speeches. Then, I will turn my attention to the Argive alliance and the foundation of the Areopagus as they relate to the judicial aspects of Athenian foreign policy in the mid-fifth century.

18. Meier 1993: 108 asserts that the only important political references within Eumenides are to the Argive alliance. The geographic references (i.e. numbers 3 and 4 above) are, he writes, "of no great significance." 


\section{PART I: GEOGRAPHY}

The passage generally understood as a reference to Sigeum is from Athena's first speech:

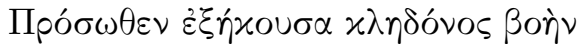

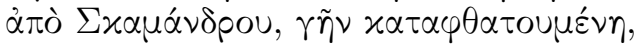

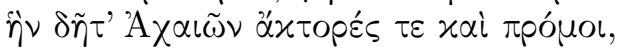

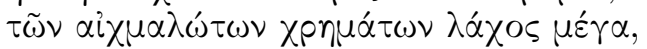

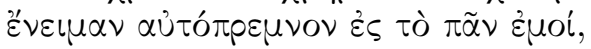

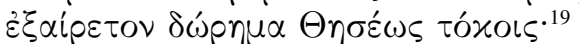

Eum. 397-402

I heard your appeal from afar, around the Scamander, where I was taking possession of the land which the leaders and foremost men of the Achaeans allotted me, root and stock, ${ }^{20}$ for all time, a great portion of the spear-won wealth, chosen as a gift for the sons of Theseus. ${ }^{21}$

The earlier scholarly discussion on these lines, beginning with the scholiasts, has focused on the conflict between Athens and Mytilene over Sigeum in the sixth century. Sigeum, located in the Troad, was acquired by the Athenians in the late seventh century and is thought to have been their first overseas possession. The scholiasts and scholars read Aeschylus' text as an Athenian claim for longstanding possession of the region, dating back to the Trojan War.

Macleod, in keeping with scholiastic tradition, suggests that, as a result of the dispute with Mytilene, the Athenians invented the myth that Theseus' sons received land at Troy as support for their claim to the region. ${ }^{22}$ He denies, however, that these lines need refer to any contemporary dispute. And this seems correct. For, when Aeschylus produced Eumenides in 458 BC, Sigeum had been back in Athenian control since the early 500s. There was no longer any dispute over that particular piece of land in the Troad. As Dover points out, "conflict with Mytilene

19. All text for Aeschylus comes from the Oxford text of Denys Page. All translations are my own unless otherwise noted.

20. This term is suggested by R. Lattimore.

21. The mention of Theseus here is interesting. Mills 1997: 56 has argued that, in Athenian tragedy, Theseus represents Athens itself. In Eumenides, though it is set mythologically in the time of Theseus' sons, Aeschylus erases them (and thereby Theseus and the kingship) from Athens. Athena, Mills argues, plays the role that would typically be assigned to Theseus in drama because Theseus, being mortal, cannot judge between gods. I am convinced, however, that Athena need not be a substitute for Theseus because of her divine status. But rather, as patron and namesake of the city, Athena fills the role of representative of Athenian interests quite appropriately. In fact, if the play participates in the dynamics of Athens' Empire, as I will argue below, Athena is the only possible figure to stand as representative of Athens. For Athena would become, after $454 \mathrm{BC}$, the official patron of the Empire/Delian League. Theseus could never truly represent Athenian imperial interests on stage as convincingly.

22. That the sons of Theseus received land in the Troad as a gift for their services in the Trojan War is not found in Homer or any of the Homeric epics. It must therefore be, as Macleod suggests, a later invention. When and where it first appeared is unknown. 
over the Troad was a phenomenon of the sixth century, not the fifth." ${ }^{23}$ For him, there is no contemporary event in the Troad warranting investigation.

Dover and Macleod, however, ignore one important point concerning Sigeum. It was among those cities that Medized during the Persian Wars and had, in fact, been under Persian control from around 490 until the Athenians liberated it in the aftermath of Salamis. Sigeum subsequently joined the Delian League along with other cities in the region and did so not as an Athenian colony or dependent, but as an equal, dues-paying member of the League. Therefore, Sigeum ranks among those cities from Aeschylus' Persians which had been freed from Persia during the glorious first offensives of the Delian League. It may not any longer have been the center of a dispute between Athens and Mytilene, but it was a sure symbol of the effectiveness of Athens' aggressive anti-Persian policy. ${ }^{24}$

Furthermore, Athena does not say that she was at Sigeum. Rather she claims that she was "beside the Scamander." Scholars have merely assumed that she refers to Sigeum. However, the Athenians had a great and immediate interest in the region that did not involve Sigeum. As soon as the Greeks went on the offensive, they attacked the Persians in the Troad and drove them out of the region, landing first in Abydos, then taking Sestos and Byzantium. ${ }^{25}$ This offensive did not involve Sigeum or the conflict with Mytilene from twenty years earlier. It was about removing the Persians from Greek-held lands-and keeping them out. ${ }^{26}$

Nor should the taking of these cities by the Athenians seem unusual or unexpected. For the Athenians did not perceive of their actions as taking foreign lands inhabited by foreign peoples. Rather the land in question had been colonized by Ionian Greeks long before and, as we are reminded by both Herodotus (5.97) and Thucydides (1.95), many Ionians considered Athens to be either their mother,

23. Dover 1957: 237.

24. Also, Podlecki 1989 in his commentary to the Eumenides suggests that there may, in fact, have been trouble in the Sigeum region in the 450s. He bases this belief on IG I ${ }^{2} 32+$ AG 11276 published by Meritt 1936. Meritt suggests that there was a possible disturbance in Sigeum with a Persian satrap and that this was a matter for the Delian League. His evidence for this is that Sigeum appears on the tribute list for the year following the incident-450/1 BC (360-61). Dodds 1973: 52 is in initial agreement with this interpretation but then concludes, evasively, that "the supposition can be neither proved nor ruled out." There were no contemporary battles in the Troad in the late 460s or early 450s. As for Athenian policy concerning the Persians, in Book 9 of his History, Herodotus describes Athenian/Greek activities in the immediate aftermath of the victory at Plataea in $479 \mathrm{BC}$, most importantly the battle at Mycale near Samos. The Greek victory at Mycale signaled the end of the Persian fleet's presence in the Aegean. Only after the battle at Mycale did the Greeks, led by the Athenians, sail to the Hellespont. By 477 BC, the Greeks controlled most of the Hellespont region.

25. This is not a geographic sleight of hand, Scamander $=$ Troad $=$ Sestos. Strabo 13.1.4 gives a wide range of ancient definitions of the Troad, most of which include Abydos and Sestos.

26. Keeping them out primarily in order to secure their food supply from the Euxine. For precisely this reason, holding onto the Hellespont would be the focus of Athenian activities for the next century. 
or kindred, city. ${ }^{27}$ Thus, the area surrounding the Scamander, which Athena was receiving as a reward for the sons of Theseus, was, in fact, land historically already populated by Athenian descendants. It was their land in $458 \mathrm{BC}$, Aeschylus' text implies, since Athena is said to have received it root and stock for all time shortly after the Trojan War. The Athenians were merely reclaiming it. And when the Ionians subsequently entered into an alliance with the Athenians as leaders of the Delian League in 478/7 BC, the Athenians, though not living in the region themselves, exerted control over the region by receiving tribute from its residents and guarding its sea lanes as if their own possession.

The geographical significance of these lines can be further demonstrated to address contemporary Athenian interests if they are read alongside Orestes' prayer:

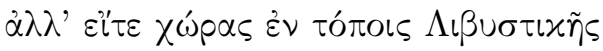

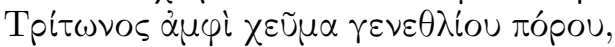

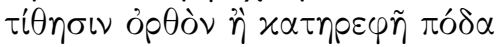

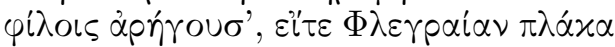

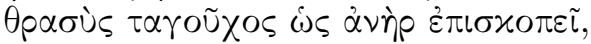

$$
\begin{aligned}
& \varepsilon \text { है } \lambda \theta \text { ol. }
\end{aligned}
$$

Eum. 292-97

But, whether in the places of the Libyan land, around the streams of the Tritonian strait, related to her birth, feet standing straight ahead or covered by a robe, a helper to her friends, or whether as a man, a brave commander, she scopes out the Phlegrean plain, may she come.

These lines have been read by some scholars as a reference to Athens' activities in Egypt in the $450 \mathrm{~s}^{28}$ The reference to Libya may reflect the fact that, according to Thucydides, it was the king of Libya who caused the revolt in Egypt and who sought Athenian support (1.104.1). Also, there may have been problems near the Phlegrean plain, which is located near Potidaea, a Corinthian colony. Dover disagrees with each of these points and dismisses them as scholarly fantasy. However, a review of the historical circumstances will demonstrate that the play may, in fact, be referring to Athenian activities in Egypt and elsewhere. ${ }^{29}$

Thucydides' Pentacontaetia is our primary source for Athenian activities in the years between 479 and 432 BC. The precise dating of the events Thucydides records in summary fashion is still heavily debated and no scholar's dating schema has been entirely accepted. ${ }^{30}$ Despite this, valuable information con-

27. Also, if we take the reinvention of Ion's genealogy by Euripides as a clue, it appears that part of the Athenian ideology of autochthony involved a myth-making process that underscored the Athenian claim as progenitors of the Ionian race.

28. Meier 1993: 107 calls these lines "an oblique reference" to the events in Egypt.

29. Podlecki 1989 on line 20, contrary to Dover, sees no difficulty in presuming that an Athenian audience would recognize a reference to Athens' recent expedition to Egypt at the request of the Libyan king Inaros. Cf. Sommerstein 1989: 292-96.

30. For two competing views, cf. Meiggs 1972: 42-204 and Badian 1993: 73-107. 
cerning Athens' rise to power can still be gleaned from the text. And, although Thucydides' chronology and account have been challenged, for our purposes the sequence he presents is sufficient for understanding the scope and type of Athenian activities prior to the production of Eumenides in $458 \mathrm{BC}$.

According to Thucydides, the first activity of the League under Athenian leadership was to take Eion in Thrace (1.98.1). After this events move rapidly. Carystos was forced to join the Delian League (1.98.3) and, shortly after this, the Athenians captured Scyros and colonized it (1.98.2) ${ }^{31}$ Naxos then attempted to leave the League but was besieged and forced to remain a member (1.98.4). ${ }^{32}$ Around the same time as affairs in Naxos were being settled, Thasos revolted and an Athenian colony was settled at Ennea Hodoi, near the Strymon River (1.100.2-3). ${ }^{33}$ Amidst all of this activity, the Athenians earned a decisive victory over the Persian fleet at Eurymedon in 467/6 BC. Around 460 BC, Athens had a fleet in Cyprus so that when the Libyan king, Inaros, attempted to put Egypt into revolt against their Persian overlords, the Athenians were able to send aid. This they did and, by $458 \mathrm{BC}$, they had sailed down the Nile and taken most of Memphis from the Persians (1.104).

While League forces were fighting in the east, the Athenians, with their allies, the Argives and Thessalians, were butting heads with the Spartans. The Argive alliance (to which I will turn shortly) was formed in $462 \mathrm{BC}$. That with the Thessalians followed shortly thereafter (1.102.4). Several of the actions of the Athenians and their mainland allies are not known; but the Athenians surely fought the Corinthians at Halieis and the Peloponnesians at Cecryphalia around 459 BC (1.105.1). Sometime after this, the theater of war shifted into Boeotia where the Spartans and their allies defeated the Athenians and theirs at Tanagra. The Athenians countered with a victory at Oenophyta about two months later (1.108.1-2). Around this same time the Athenians defeated the Aeginetans and brought them into the League (1.108.3-5). This takes us up to (and slightly beyond) the time of production for Eumenides in $458 \mathrm{BC}$.

What, then, is the significance of these events for understanding Eumenides? In order to answer this question, it seems appropriate to examine Dover's opposition to allusions in Eumenides to Athens' activities abroad during the 460s BC. Dover's first point is that the Athenian force in Egypt fought in the Delta,

31. It was at this time that Cimon is said to have recovered the bones of the Athenian hero Theseus. Theseus, as a result of a crime he committed, was forced to leave Athens and wound up an exile on Scyros where he died. His bones were taken back to Athens and reburied by Cimon after their discovery. For a discussion on the significance of Cimon's act, cf. Castriota 1992: esp. ch. 2; Connor 1993: 115-20; Garland 1992: 82-98; Mills 1997; Simon 1996: 9-26; Walker 1995: 56-57.

32. Thucydides remarks here that by the time Naxos was beaten into submission, the Athenians

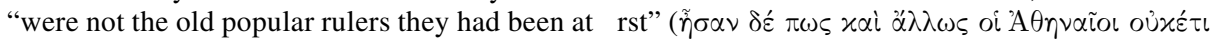

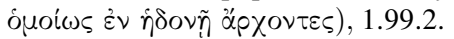

33. This is the precursor to Amphipolis. The colony at Ennea Hodoi was wiped out in the 450s by Thracians, but was successfully resettled as Amphipolis in 437/6 BC. 
not in Libya. ${ }^{34}$ This is true from our modern perspective. The Athenian fleet sailed down the Delta and established itself at Memphis. However, Dover's point is that, since some Greeks considered Libya to begin at the west bank of the Nile and did not include the Delta, Aeschylus, therefore, could not possibly be referring to Egypt. This is a rather narrow interpretation. ${ }^{35}$ Herodotus states that the borders of Libya were conceived of as beginning as close to the Nile as the west bank (2.16.1). He does go on to suggest that the Delta proper belongs to neither Libya nor Egypt, but he is clearly arguing against a commonly held conception of land divisions. ${ }^{36}$ This means that the imagined borders were fluid, not really decided upon or fixed, and "Libya" could serve poetically as a general point of reference for a region that included the Delta.

In addition, as Dodds points out, "The ancients had no war correspondents and no maps of the front. Probably neither the poet nor the majority of his audience would be in a position to know just where the battles were taking place; what they would know is that many of their kinsfolk were overseas, fighting for the Libyans." ${ }^{37}$ The boundaries between Libya and Egypt are vague in the sources and perhaps also so in reality. It was also the case that, regardless of the distinction Dover makes, some Greeks used the name Libya to represent the whole continent of Africa. Indeed, Hecataeus' map, produced sometime in the early part of the fifth century, does exactly this. Herodotus attempts to change this perception by separating the Delta from Libya, but this does not mean that he succeeded in convincing his audience that his geography is the correct geography. At the time of Aeschylus' play (three decades or more before Herodotus' work was released), it may have been very common not to distinguish between Libya, the continent, and the Nile Delta, a place on the continent.

Dover's next argument concerns line 293 where the Triton River is specified, a river located, according to Herodotus 4.180, in the far west of Libya, not near Egypt. The association of Athena with Lake Tritonis suggested by $\gamma \varepsilon v \varepsilon \theta \lambda$ iou is the purpose, Dover states, of its mention. And this is, I think, absolutely correct. However, just as with Dover's arguments concerning Libya in general, there is nothing to prevent us from interpreting the reference to the Triton River as part of a larger reference to Athenian activities in the Delta during the early $450 \mathrm{~s}$ while still acknowledging its propagandistic aspect. The Triton River is located,

34. Dover 1957: 237.

35. Contrary to Dover, Sommerstein 1996: 397 states, "an audience who has just been reminded, by mention of the Argive alliance, of the great war in which their city was engaged, and heard them tell of Athena 'aiding her friends' in Africa, could not help thinking of the vast Athenian force even then fighting on the banks of the Nile."

36. Herodotus goes to great lengths between 2.15 and 2.17 to define what Egypt is and what Libya is and what the relationship of both is to the Delta. The extent and tone of these passages suggest he is arguing against the grain.

37. Dodds 1973: 47 
according to Herodotus, near Cyrene. ${ }^{38}$ In 454 BC after their defeat, the survivors crossed through Libya to Cyrene on the northwest coast, which suggests that at least part of Libya was familiar to the Athenians (Thuc. 1.110.1) ${ }^{39}$ Cyrene was a Greek city (an early colony of Thera) and it makes sense that, if the Athenians retreated to Cyrene after their defeat in $454 \mathrm{BC}$, they would have had contacts with the city earlier on in the campaign and even possibly used the city as a supply and communications point.

This is underscored by the justification for Athenians being in the region provided by $\gamma \varepsilon \nu \varepsilon \theta \lambda i$ iou. Just as it is suggested above that the Athenians were "reclaiming" the Troad for their kin, the Athenians may have claimed likewise in Libya that they had an intimate connection with the region; indeed, their patron, in one version of the myth, was born there. ${ }^{40}$ And Athena was not just any patron goddess. She is the representative of the city. ${ }^{41}$ It was men of her city who were fighting against the Persian menace in Egypt. If the Athenians could claim, yet again, to be reclaiming lands seized by the Persian tyrant, they could justify, yet again, their aggressive military activities abroad. ${ }^{42}$

38. It is interesting to note that there are two other Triton Rivers that are claimed as Athena's birthplace. Both are mentioned in Pausanias. The first is a spring in Arcadia where a statue, which Pausanias assumes is Athena, is worshipped (8.26). The second is in Boeotia. The Boeotians actually have, according to Pausanias, a temple honoring Athena Tritogenia (9.33).

39. It also suggests that there was a high level of interaction between the Athenians and Libyans during the six years of conflict. The Libyans were their allies. Nor is it necessary that the Athenians operated entirely in or out of Memphis. They probably got supplies and support from the Libyan king.

40. There is a question as to whether a reference to an alternative myth of Athena's birth might in some way undercut the bond explicitly created throughout the trilogy between Athena and Zeus as

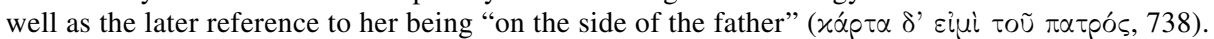
But it seems implausible that the $\gamma \varepsilon v \varepsilon \theta \lambda i$ iou can refer to anything else in association with the Triton reference. It is quite possible that the Athenians had no difficulty referring to alternate myths when it suited their purposes and to the more "standardized" versions when that suited their purposes. No one has ever suggested that the ancient Greeks, be they Athenians or otherwise, were consistent in their mythology.

41. As I stated above (n. 21), Athena is a true representative of Athens and its interests on stage. This conclusion is supported by Papadopoulou 2001: 304. She cites Eumenides as the "most influential portrayal of Athena as the deity of Athens and its institutions." Sommerstein 1989: 133 also points out that the term $\alpha 2 \nu \alpha \sigma \sigma \alpha$ is used at Eum. 288 (and 443) to refer to Athena and this implies that Athena, not Theseus' sons, is the "king" of Athens. What this means is that the city of Athens consists of Athena and her citizens only, making the Athenians subject to no man and ultimately the most free of Greeks. The implication that Athens and the city are one is also implicit in their very names since Athens does not mean "the city of Athena" but is the plural of Athena; thus the citizens are themselves little "Athenas."

42. The story concerning the Triton River and Cyrene at Herodotus $4.178-80$ is quite interesting in this regard. For not only is it claimed that Greeks from Thera (the descendants of the Argonauts) settled the city, but also that an oracle proclaimed that the Spartans would have colonies around the river and lake. The Spartans never really did found any colonies, but Herodotus tells us that the sons of the Argonauts went to Thera after leaving Sparta. Whether the Athenian claim on the Triton region had anything to do with the Spartan association with the location is uncertain, but interesting to speculate about. 
Next, Dover states that there is no evidence for trouble in Potidaea, near the

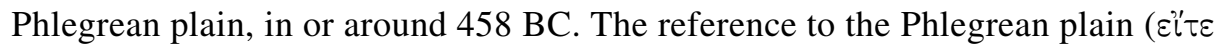

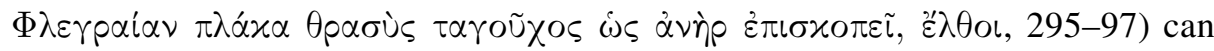
easily be accounted for, he suggests, by referring to the battle with the Giants in which Athena played a prominent role. This may be so. But there is no protocol that demands that it can only refer to that battle. Nor is it necessarily the case that "Phlegrean plain" must refer specifically to Potidaea. Just as with the reference to the Troad above, the Phlegrean plain is a large region encompassing parts of the Chalcidean peninsula and is, according to Herodotus (7.123), an ancient name for Pallene in Thrace. And while there was no known activity in Potidaea proper at the time immediately preceding the production of Eumenides, there was a great deal of activity in the Strymon River valley near Thrace. Eion was taken in 477 BC, Ennea Hodoi founded around 465 BC, and Thasos was reduced also around the same time. ${ }^{43}$ Since maps were not common, a broad reference to a well-known location like the plain may have served as a point of reference for the audience.

Arguments against the contemporary value of geographic references at lines 292-97 and 397-402 are not decisive. It can be demonstrated that these references, while not reflective necessarily of particular battles or events, do mirror larger patterns of events. The Athenians had a vested interest in the Troad as early as 479 $\mathrm{BC}$ and continued to maintain a presence there for most of the next two centuries. They were active in Libya and Thrace in the early 460s and late 450s. The overall picture that emerges from a discussion of these regions taken all together seems to point to a defined (or, rather, suggested) range of activity (Fig. 1). ${ }^{44}$ The locations in question are each at the extreme boundaries of Athenian activity. They are each associated with the whereabouts of Athena. Athena is the representative of Athens and Athenian interests in Eumenides. Thus, the regions can also be associated with the whereabouts or interests of the Athenians at the time.

In addition to this, it is interesting that each of the regions in question can, in one way or another, be associated with Athena or Athens in mythology. Macleod claims that the Athenians invented a myth concerning the sons of Theseus and Athena's land allotment in the Troad in the sixth century to support their claim to Sigeum against Mytilene. The same myth, as has already been suggested, can also refer to the claim of the Athenians that they were "reclaiming" the region

43. Meiggs' doubts concerning the attempted earlier settlement of Ennea Hodoi in $476 / 5$ BC are not compelling since he argues only from Thucydides' silence on the issue and this is always a dangerous tack to take. In addition, just as with the earlier discussion of the Troad, Amphipolis (the later name for Ennea Hodoi) was claimed by the Athenians as a dowry for Theseus (Aeschines 2.31). And, although the Athenian audiences for Aeschylus and Aeschines are not the same, the fact that it occurs in the orators at all attests to its propaganda value. By Aeschines' time, the appeal to Theseus must have been a common part of the Athenian claim to the region.

44. This runs counter to Euben's 1990: 76 statement that, "unlike the unconfined daring of Thucydides' Athenians, those in the Eumenides are still patient with their inheritance." The Athenians had a fleet roaming the Aegean, troops in Egypt and were about to embark upon a war with Aegina. This does not seem very "patient" to me. Fig. 1 appears below, p. 69 
from the Persians for their Ionian kin. The reference to the Tritonian strait can be associated with an alternate myth of Athena's birth. According to Herodotus 4.180, the Libyans had a myth that Athena's father was not Zeus, but Poseidon, and that she was born from Lake Tritonis in western Libya. One of Athena's Homeric epithets is Tritogeneia, triton-born (or "third-born"), and may reflect this alternate version of Athena's birth. If understood as reference to this alternate myth, it would be yet another example of the Athenians using myth to further their imperial claims. And, as Dover points out, Phlegra was the site of a great battle against the Giants in which Athena played a central role.

Mention of each of these locations has a two-fold purpose. First, they suggest known spheres of military action to the audience. Second, they supply a mythological precedent or charter for Athenian presence in those regions. Both of these purposes lie at the heart of patriotism and link it explicitly to an expansionist agenda. That this is the case is further strengthened by the preponderance of military language that surrounds the geographic references.

While I will turn to the language of the text shortly, I would like to first summarize the discussion of geography above in order to emphasize the connection between geography and the imperial undertone of Eumenides. I have argued thus far that we need to pay attention to the geographic references in the play because they are neither random nor unimportant, and have suggested further that they contribute to a pro-imperialist ideology and expansionist agenda. The passages we have considered appear to involve a certain degree of intentionality on the part of the author which I have claimed is in some ways irrelevant to my discussion at least with regard to the broader ideological dynamics. What, then, was Aeschylus' "intention" in including these references?

It seems that we have two possibilities. The first is that Aeschylus was, as Meier suggests, playing on the patriotic fervor of the Athenians by reminding them about the newly re-conquered territories, about Greeks they had "saved" from the Persian menace. The second, more in line with Rosenbloom, would be that these reminders of Athenian troop placements would serve as warnings against such adventurism. Retrospectively, perhaps one could agree with a Rosenbloomian analysis of an imperialist geography of Eumenides since the Athenians would, in fact, suffer a devastating defeat in Egypt only a few years following the trilogy's production. Two things, however, argue against this interpretation and suggest one more closely akin to an appeal to patriotism.

First, Rosenbloom's insistence that the text undermines and questions imperialism is based on the connection of naval words and imagery with Agamemnon, whom Rosenbloom understands as a negative character. ${ }^{45}$ Agamemnon, however, is not the one being found in the four corners of the Aegean in Eumenides. It is Athena-and this makes a difference. As noted above, Athena in Eumenides is the

45. For a brief criticism of Rosenbloom's representation of Agamemnon as a negative example of naval adventurism, cf. Griffith 1995: 79n.66. 
"most influential portrayal of Athena as the deity of Athens and its institutions." 46 The goddess is the city, the city the goddess. And, unlike Agamemnon, Athena is not sullied by any negative associations with eastern tyrants and violence. ${ }^{47}$ In fact, she is, as we shall see, the very fount of democratic principles. Thus when it is Athena associated with such adventurism, it surely becomes positive and patriotic rather than worrisome and ironic.

The second reason why an anti-imperialist interpretation is questionable has to do with the intimate relationship between imperialism and geography. Saïd, writing of the emergence in Cold War Europe of a more geographically aware "world literature," says:

But in this geographically articulated vision (much of it based ... on the cartographic results of actual geographical exploration and conquest) there is no less strong a commitment to the belief that European preeminence is natural, the culmination of ... various "historical advantages" that allowed Europe to override the "natural advantages" of the more fertile, wealthy and accessible regions it controlled. ${ }^{48}$

Geographical material, some of it directly related to actual exploration and occupation, by its very presence within a text, plays into a world vision that ultimately justifies the possession of that territory by the culture that produces the literature. In fact, Saïd goes on, "To their audiences in the late nineteenth and early twentieth centuries, the great geographical synthesizers offered technical explanations for ready political actualities." 49

Our analysis of the geographic passages in Eumenides has revealed a similar interrelationship between exploration, conquest and expanding knowledge on the part of the Athenians in a combination that appears consciously to promote a positive and unified notion of national expansion and aggrandizement. The audience itself is eager to hear of these newly re-conquered or surveyed territories and the playwright, as a member of the same socio-political unit as his audience, supplies the references with the same eagerness. The abundance of such geographies in most of Aeschylus' surviving plays attests to this phenomenon. Thus, the figure of Athena serves symbolically within Eumenides to mark domains either under

46. Papadopoulou 2001: 304.

47. On Agamemnon as negatively portrayed eastern tyrant, cf. Rosenbloom 1995: 106-109. There are a number of other "negative" terms that shift meaning from the first to third plays of the trilogy. The purple cloth upon which Agamemnon tramples (Ag. 946-48) becomes the purple robes symbolizing the Erinyes' new status as metoikoi (Eum. 1011,1018). vixn, originally associated with

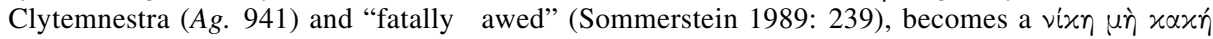
(903) for Athena and Athens. It is a victory, moreover, explicitly tied to other positive forces such as $\delta i x \eta$ and $\sigma \omega$ tnpi $\alpha$ and gained not through force of arms but through persuasion. Thus there is a general shift between Agamemnon and Eumenides. Terms associated negatively with the House of Atreus in Agamemnon become positives when associated with Athena and Athens in Eumenides.

48. E. Saïd 1993: 48.

49. E. Saïd 1993: 48. 
Athenian control or currently under some form of exploration or colonization (Fig. 1). The references, taken all together, provide the Athenians with an imaginary map, a map that demonstrates the far reach of Athens. The extent of the reach then justifies and reinforces the patriotism an Athenian might experience at hearing the verbal mapping. ${ }^{50}$ Again, as Saïd states of Europe, "Europe did command the world; the imperial map did license cultural vision." ${ }_{51}$ The same could be said of Athens.

That the geography of Aeschylus is inherently imperialist is probably not, however, part of Aeschylus' intention. His intentions seem to be to engage the interest of his audience, to enter into a new genre of discourse and to derive dramatic capital from the growing awareness of the Athenian audience of their influence (and necessity) outside of Attica. But precisely because the Athenian world-vision is focused outward with a hegemonic eye toward acquiring power and influence, it is impossible for Aeschylus' geography to avoid expressing an imperialist ideology.

\section{PART II: JUSTICE}

But there is another element in the play that binds the geography even more strongly to empire, and that is the concept of justice. That a major theme of the Oresteia is the transformation of justice from personal/familial and retributive to institutionalized is well accepted. What has not been discussed, however, is the notion of this court-style justice as it relates both to the development of Athenian civic identity and to the development of an imperial ideology. In order to bring home the importance of the geographical elements of Eumenides and to demonstrate even further the ultimate connection between geography and imperialism, I will turn now to a discussion of the judicial elements of the text.

The foundation of the Areopagus is explicitly linked in the play with the geographic references already discussed. The establishment of the map is even, I suggest, a necessary precursor to the establishment of the tribunal. The map created by plotting the locations whence Athena has come or that she herself mentions is competed by line 402. It is not until afterwards that the trial begins and the court is established. When Athena does, at last, get to the business of founding the Areopagus, she directly recalls her previous geography:

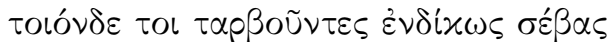

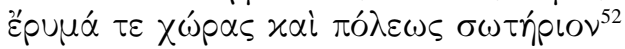

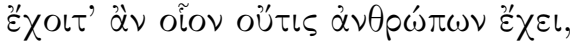

50. Recall Meier 1993: 70, "with what pride must the Athenians have listened to the long catalogue of Greek cities which had been conquered by Darius only to be liberated by Athens!"

51. E. Saïd 1993: 48.

52. This phrase, Sommerstein 1989: 219 points out, is used by Lysias in the fourth century to refer specifically to the Areopagus. 


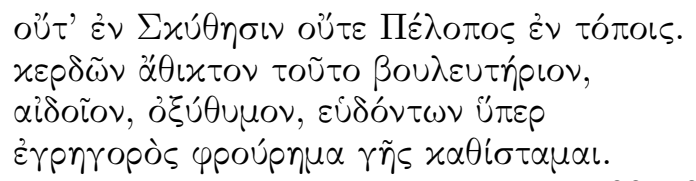

Eum. 700-706

Stand in just awe of such majesty, and you will have a defense for your land and salvation of your city, such as no man has, either among the Scythians or in Pelops' realm. I establish this tribunal, untouched by greed, worthy of reverence, quick to anger, awake on behalf of those who sleep, a guardian of the land.

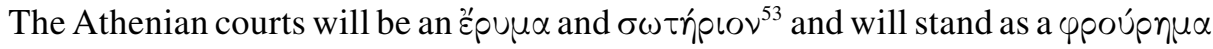
rñ unlike any found in the Peloponnese or Scythia. Both Scythian and Spartan societies were referred to as having eunomia. ${ }^{54}$ They are also both absolutely outside of the zone enclosed by the earlier geography (Fig. 1). Thus, when Athena establishes her court, she does so with a blatant reminder of its jurisdiction, a jurisdiction I have suggested coincides with both Athenian imperial aspirations and already actualized hegemony. She also suggests her court is an alternative to or supercedes the eunomia of those other cultures.

The Areopagus is clearly linked to the geography of the text. But is it therefore overtly imperial in nature as I have argued the geography is? The answer to this lies in recognizing the nature of the court itself, what type of cases are to be tried and who will be tried in front of the court. I begin by addressing the nature of the court. I will then turn to the types of cases, followed by the actual participants. What I intend to show is that the geographical reference in the foundation speech entails a recognition of the larger context both of this court and of the Athenian conception of justice. This court is the manifestation of an Athenian identity created by association with the democratic freedoms of trial by jury. But it is also very much an identity that grows to serve power instead of freedom.

Much has been said by scholars concerning the foundation of the homicide court on the Areopagus by Athena at lines 681-710 of Eumenides. That scholarship, however, has focused on two points involving the founding of the court: one, its precise relationship to the reforms of Ephialtes in $462 \mathrm{BC}$ and two, more abstractly, its relevance for a study of the relationship between the demos and old aristocracy in Athens in the mid-fifth century. On the first point, most of what has been written involves whether or not Aeschylus himself supported the reforms. ${ }^{55}$

A discussion of the second point is not as clear-cut. For any interpretation necessarily depends on how one reads the first point. But if we read the play within the dynamic of the ideologies of power and freedom then authorial intent

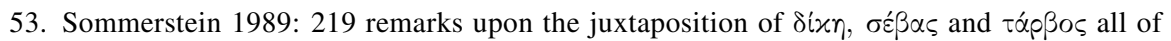
which, he says, are necessary for $\sigma \omega$ tnpi $\alpha$.

54. Cf. Sommerstein 1989: 219.

55. See above, n. 15. 
on this matter becomes impossible to reclaim. Also, the decision on Aeschylus' intention is intimately linked to the scholars' own beliefs and will never ultimately be decided one way or another. For these reasons, I will not address here the issue of Aeschylus' intentions in mentioning the Areopagus. Instead, I will examine some of the implications behind representing a court of this kind on stage at all. One aspect of the founding of the court by Athena that has been largely overlooked by scholars is the implication of a court's function in an imperial context. Besides the geography already mentioned, Orestes himself is not an Athenian being tried in an Athenian courtroom. He is a summachos being tried in an Athenian court. This suggests a different dynamic within the court from what is envisioned when reading the play within the context of Ephialtes' reforms alone.

It may seem a slippery argument to move this court, which is specifically associated with the Areopagus, from an internal context to an imperial one. But the text itself does make the shift. The trial of Orestes that is presented to the audience does not at all closely resemble a homicide trial in front of the real Areopagus. The Areopagus was the court where after Ephialtes' reforms, it seems, only cases in which an Athenian citizen was intentionally murdered were tried. ${ }^{56}$ Since no Athenian citizens are involved in this case it would more rightly be tried by the polemarch. ${ }^{57}$

The Areopagus itself may have held jurisdiction over homicide as early as the seventh century and certainly did, with the Basileus at its head, in the fifth and fourth, ${ }^{58}$ but the case that is presented on stage to the audience does not reflect actual homicide trials before the Areopagus. For one thing, homicide trials required elaborate rituals like the three pre-trials (prodikasiai), and these jurors are called dikastai, whereas the judges from the Areopagus were not referred to in that manner by the Athenians. ${ }^{59}$ As Podlecki points out, "Whatever legal niceties and hypothetical pleas available to a latter-day Orestes, in the primordial, pre-legal period of Athens' history, Orestes is to be tried before the Areopagus."

In other words, the case of Orestes would have been recognizable to audience members as an atypical trial for the Areopagus. They would have been expected to suspend their disbelief and accept Aeschylus' mythical account as a charter

56. MacDowell 1978: 117.

57. According to the Phaselis Decree ( $\mathrm{IG} \mathrm{I}^{3}$ 10), the earliest known reference to judicial restrictions of allies, cases for allies would have been tried $\pi \alpha \rho \grave{\alpha} \tau \tilde{\omega} \iota \pi \circ \lambda \varepsilon \mu \alpha \rho \rho \omega \iota$, not in the Areopagus. But it is possible that the decree comes prior to the reforms of Ephialtes in $462 \mathrm{BC}$, and it is thought that, before those reforms, magistrates such as the polemarch held more power in the courts. For a discussion on the date of the Phaselis decree, see below, n. 64.

58. MacDowell 1978: 27.

59. Cf. Sommerstein 1989: 15-17.

60. Podlecki 1989: 204. It is also interesting to point out that Greek homicide laws were of a different kind from most legal protections. In his discussion of pollution, Parker 1983: 116 suggests that homicide laws themselves often ignore the concept of pollution and are actually throwbacks to the age of retributive justice. He sees this as especially the case when considering cases of inanimate objects. The idea is not to cleanse the population of a possible pollution threat, but rather to exact some payment for the crime, recover damages for irreversible harm done. 
for Athenian legal institutions in general. What I am suggesting, therefore, is that we need not associate this court with the reforms of Ephialtes at all. Rather, the Areopagus becomes symbolic of all courts in Athens, thereby fostering a democratic identity for the Athenians associated specifically with the concept of justice as trial by jury. ${ }^{61}$ The distinctions between the Areopagus of Ephialtes' reforms and the court enforcing Athenian judicial hegemony in the empire are thereby blurred by the very nature of the representation. And this distinction is blurred even further when the identities of the defendant and plaintiff are taken into consideration, since neither Orestes nor the Erinyes are Athenians. But, each one is given a distinctive association with Athens during the course of the play. The Erinyes by the end of the play will become metics, resident aliens, in Athens, while Orestes, whose identification is most pertinent to out current discussion, comes to Athens as a summachos.

The word summachos, "ally," is, in the fifth century and later, the term used in inscriptions to denote the military relationship between Athens and other Greeks who attached themselves to her. Thus the term links in this context, absolutely, the military and judicial aspects of an ally relationship. It occurs nowhere in Homer, making its earliest appearance in the lyric poets. ${ }^{62}$ In Aeschylus' extant tragedies, summachos occurs seven times and is used, each time, to denote either a military or, in the case of Choephoroi, pseudo-military alliance. ${ }^{63}$ It is most likely that this was the word used in the original agreements between the members of the Delian League in 478 BC. $^{64}$ The use of the word summachos here to introduce

61. Does Aeschylus intentionally represent the court this way? Yes, absolutely. But certainly we can never know to what end exactly. It is more likely, however, that the larger context implied by his representation of the court is the product of forces working on and through Aeschylus rather than the playwright's intentionally creating a reference to a very recent Athenian judicial practice. The Athenians, I will argue in what follows, came to identify their freedom and power specifically with courts. This is not in and of itself imperialist. Only when we see the convergence of geography, real imperial practice and art do we make the connection. Aeschylus, I think, was not in a position to recognize this convergence, but was rather caught up in it.

62. Sappho 1.28; Archilochus 108.1; Tyrtaeus 3b, 580; and Alcaeus 350.3 (participle).

63. I call the alliance in Choephoroi a "pseudo-military" alliance since it is an alliance against a physical threat and it culminates in the characters' taking physical action against the other party. The first occurs at 19 where Orestes asks Zeus to stand and fight with him against his enemies. The second is at 497 where Orestes calls on Dike as his ally. Both of these instances are interesting in light of what happens in Eumenides. Orestes finds "justice" in the court at Athens, and the daughter of Zeus (Athena mentions that fact numerous times) becomes his summachos. On this relationship between Orestes and Athena/Zeus as a xenia relationship, cf. Griffith 1995: 68-81 and below, n. 66.

64. The earliest use in an inscription that remains is the Phaselis decree (IG $\mathrm{I}^{3} 10$ ), dated by Meiggs and Lewis between 469 and 450 BC. The dating of this and many of the other inscriptions discussed in this article is debated. Meiggs and Lewis, Wade-Gery and de St. Croix all agree on a window between 469 and 450 BC. Fornara and Sealey suggest a date closer to 450 BC. Mattingly has argued extensively for a date for this decree and many others of 428/7 BC or later but has yet to convince other scholars for the most part. While the debate over the date focuses in on the shape of letters, there is much at stake ideologically if we accept an earlier date. I am inclined to disagree with Mattingly's insistence that it only makes sense to date this decree and many others to the 
the appeal by Orestes for Athena's aid at lines 271-79 colors the meaning of the appeal itself. Its use and context force us (or, at least, ask us) to consider what type of alliance is being offered. It is an alliance covering both military and judicial matters and it is with an Athena whose influence stretches from Libya to Thrace. ${ }^{65}$

Three times within the context of the play, summachos is used (289-91, 669$73,762-74)$. It is generally accepted by scholars that these instances refer to the alliance between Argos and Athens in 462 BC. However, who is to say that the Argive alliance is the only alliance meant here? A close examination of the passages in question will demonstrate that the Argive alliance as portrayed in Eumenides is being idealized within the text as an exemplary alliance.

The first passage in which the Argive alliance is mentioned occurs at 289-91. Orestes proclaims:

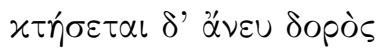

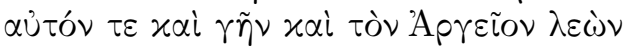

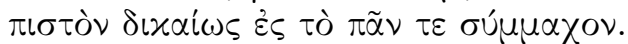

$$
\begin{aligned}
& \text { Eum. 289-91 }
\end{aligned}
$$

She will obtain without her spear myself and the land and the Argive people as a trustworthy ally justly for all time.

Athena will become an ally of the Argive people. This much is not disputed and seems clear. But why does Orestes say "without spear"? The meaning of the phrase is, of course, that the alliance is agreed upon between two cities at peace with one another, that it is not a forced alliance coming as a result of any military action or threat. But the implication behind "without spear" is that Athena/Athens must have made allies "with a spear" - meaning she gained other alliances by force. ${ }^{66}$

What summachoi did Athena/Athens gain "by the spear" up to 458 BC other than certain members of the Delian League, namely Carystos, Naxos, Thasos, Andros and, shortly after the performance of Eumenides, Aegina? Each of

Peloponnesian War era when Athens was unashamedly an imperial power. My reading of Eumenides and my understanding of Aeschylean tragedy in general leads me to conclude that the historical and cultural criteria understood by Mattingly to define imperial Athens were already present as far back as the 460s BC, maybe even earlier, though the Athenians themselves may not have been aware of a full-blown imperial ideology at that time. In all instances, I am in agreement with the majority opinion against Mattingly concerning the earlier dating of these decrees.

65. It is also interesting that all of the regions mentioned both here and at 397-402 (Libya, Thrace and the Troad) are places taken by Darius in the years before Marathon. These regions were all among the first taken back during the early offensive activities of the Delian League. The same dynamic is perceived by Rosenbloom and Meier concerning the geography of Persae.

66. Griffith 1995: 100 argues that this phrase is referring to the fact that Orestes via Agamemnon

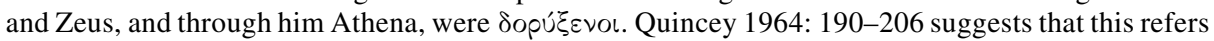
to an alliance in which the Athenians would not be required to give military aid to those allies in the future. Neither of these views is mutually exclusive. Of course, the reference in 773 to $\sigma \cup \mu \mu \alpha \chi^{\prime} \chi \omega \iota$ Sopi suggests that Quincey is incorrect. 
these allies was either forced to join the League or was forced to return to it after revolting. Thus, I suggest that the Argive alliance, in which the Argives were willing participants, suggests a model alliance. Others too should become

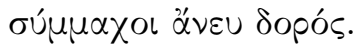

This idea of becoming a willing ally of Athens is further complicated however, since the ally in question will be asked to lift those same spears against others. Summachos occurs again at 773 in Orestes' speech of thanks to Athena after his acquittal, and addresses just this instance:

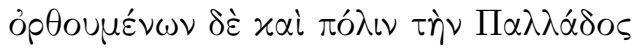

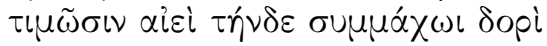

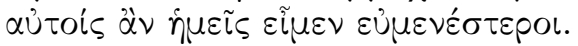

$$
\begin{aligned}
& \text { Eum. 772-74 }
\end{aligned}
$$

But to those who keep their oath and honor this city of Pallas always with an allied spear we would be quite well disposed.

In this instance, as in the first, Orestes is pledging himself and his descendants to Athena/Athens. The Argive-Athenian alliance will be one of mutual friends and enemies. Orestes/Argos will befriend those who keep their oaths to Athena/Athens and, as Orestes states in the preceding lines (763-70), Argos will neither attack Athens nor allow any other, breaking their oath, to do so. Just as with the word summachos, this concept of having the same friends and enemies is part of the technical aspects of the treaties between Athens and her allies. ${ }^{67}$ And it is interesting to note that Orestes will punish not just anyone who dishonors Athens, but specifically those who are breaking such an oath.

When the Delian League was formed, iron was thrown into the sea as part of the oath-taking. ${ }^{6}$ This was meant to signify that the alliances formed were for all time. Naxos and Thasos were the first to break that oath and attempt to leave the League. Athens laid siege to them both until they returned and the other allies appear not to have attempted to prevent it. Instead, the others continued to contribute either ships or money even though those resources were being used against fellow Greeks and not the Persian menace. Unlike some allies, Orestes/Argos will not break his oath. And if others do, Argos will punish them on behalf of or alongside of Athena/Athens.

In these two passages, Orestes/Argos appears a model ally. Argos has allied itself willingly with Athens; it has not been compelled. Also, Argos will maintain the same friends and enemies as Athens and will punish other allies who break the same oaths. Taken in tandem with the geography of the text as well as the explicit

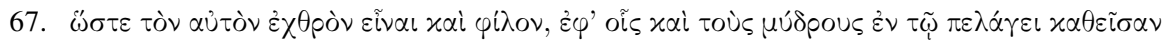
(Aristotle $A P$ 23.5).

68. Also, Garland 1992: 96 states, when discussing the nature of divine punishment under the demos in classical Athens, that a broken oath amounted to "contempt for their [the demos'] majesty." Thus the sort of oath Orestes was swearing would have been to uphold the demos and so the democracy. 
reference to the geography in Athena's foundation speech, these references seem to reach beyond the Argive alliance of $462 \mathrm{BC}$ to include other aspects of Athenian foreign policy, especially those pertinent to their "allies."

The relationship between the court of Eumenides and actual imperial practice established by the geographic references can be taken further still. First, in addition to the use of summachos, the language in which both Athena and Orestes are mentioned suggests a military context for the geography and the judicial proceedings. Second, the language of the alliance and the very nature of Athena's position with regards to the defendants is reminiscent of actual inscriptions imposing restrictions on actual allies.

That the regions mentioned are militarily significant is suggested by the language of 292-97. Dover argues that the use of the militarily suggestive yí

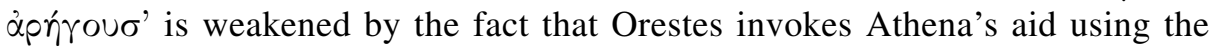

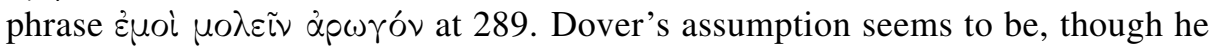
does not make it explicit, that $\alpha$ pwrós is being used to mean an "advocate" in court as it is used in the description of the peaceful city at Iliad 18.502. However, there is nothing to suggest that this word is not equally applicable to a military situation. As a matter of fact, it is used in a military sense at Iliad 8.205, and there is no reason why the word cannot carry both a legal and military connotation at once. ${ }^{69}$ Also, when Aeschylus is specifically referring to an advocate at court,

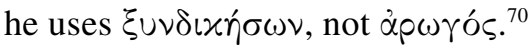

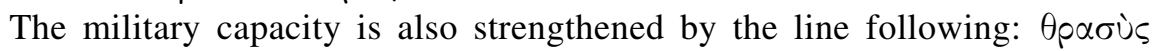

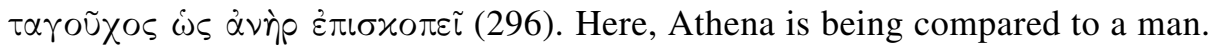
And not just a man, but a brave one, a military leader, scanning the landscape.

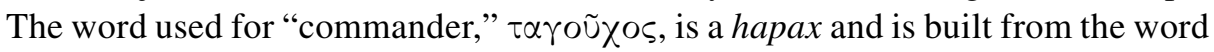
$\tau \alpha \gamma o ́ s$, which is used repeatedly in the Persae to refer to military commanders. $\tau \alpha \gamma o \tilde{u} \chi 0 \varsigma$, in addition to the technical term summachos, places the geography

69. The other uses in the Iliad are equally ambiguous: 4.235, 408; $21.360,428 ; 23.574$.

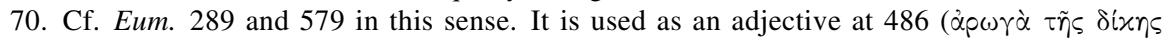
$\delta \rho \chi(\omega) \alpha \tau \alpha)$ in the sense of "useful" or "serviceable." In Agamemnon, the term appears at line 47

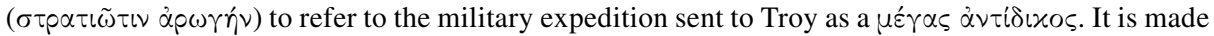
very clear that the military expedition itself is the opponent in a lawsuit of sorts, but one tried by strength of arms. In Agamemnon, the term is of ambiguous moral value since it refers to an expedition that is inaugurated by an unlawful sacrifice ( $\theta \cup \sigma i \alpha \nu \alpha \alpha^{\prime} \nu \mu o \nu, A g$. 150) and that is characterized as

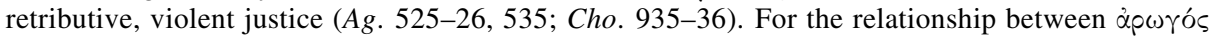
and $\alpha \nu \tau i \delta$ ¿ Trojan War in Agamemnon, cf. Daube 1939: 96-124. The association of hubris with the war is also discussed by Daube at 119-21. In Eumenides, however, it is Athena who is àpwrós, a god untainted

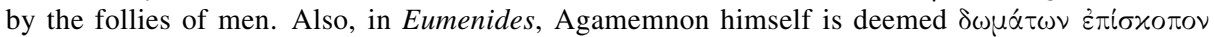
by Athena, and $\varepsilon \pi i \sigma x o \pi \circ \varsigma$ is a term clearly associated with Athena herself within the context of Eumenides. $\alpha$ porós appears in Aeschylus and then gets used by Plato and the orators as a legal term. It occurs especially frequently in Plato's Laws. It also becomes a common term in inscriptions from the second century BC onwards. It is interesting to note Aeschylus' use at Supplices 726, where

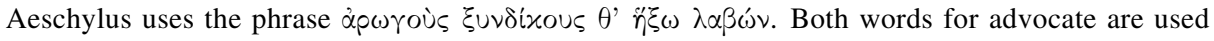
together as if apwrós alone were not clear enough. 
and also the court proceedings squarely in the realm of military (and allied) action.

The nature of the relationship between the defendants and Athena is also suggestive. In a speech by Apollo to Athena Apollo says:

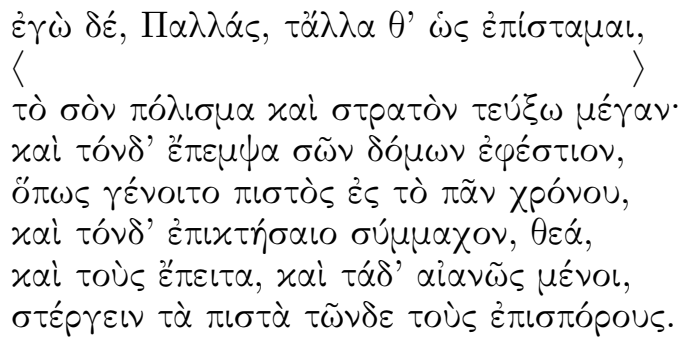

Eum. 667-73

But I, Pallas, as much as I understand other things, <

$>$ I will make your city and army great. And so I sent this man to the hearth of your home so that he might become a trusted friend for all time and so that you might gain both this man as an ally, goddess, and also those still to come, and that the descendants of those men accept gladly these trustworthy deeds.

Here, Apollo claims he sent Orestes to Athens so that they, the Argives and Athenians, might become allies. First, the alliance, if one reads Orestes' supplication and Apollo's speech correctly, implies an alliance of non-equals. At $235 \mathrm{ff}$., Orestes/Argos kneels before Athena/Athens clutching the feet of her statue in supplication. After the trial, Orestes still does not stand before Athena as an equal. He is a man awaiting judgment before a god. Thus the alliance of Athens and Argos cannot but be one between unequal members-especially since even Apollo, himself a god, defers to Athena and her Athenians.

Second, we must consider why Apollo would send Orestes to Athens at all. Why can Orestes only find justice in Athens? Why can it be found only in the presence of Athena? One explanation would be that, despite Apollo's purification of Orestes, the Erinyes will continue, Apollo says, to hunt him. Parker states that, although Apollo is known in the fifth century as the "purifier of men's houses" and he who "washes away" evil, he is not known directly as a purifier of murderers. Rather it is Zeus who offers purification. Therefore, Athena stands as proxy for Zeus. ${ }^{71}$ But because Apollo ordered Orestes to kill his mother, he can be freed from the Erinyes by a judgment. ${ }^{72}$ It seems that, according to this play anyway,

71. Parker 1983: 138.

72. Parker 1983: 140. Apollo feels responsible for Orestes since he acted on authority of the god's oracle. Perhaps this can also be understood as Apollo recusing himself because of prior involvement with the defendant. Similar logic may have been used to justify Athenian jurisdiction in reality. A Samian or Corcyrean jury might not be trusted to judge its fellow citizens according to Athenian interests. 
the only place Apollo himself can stand trial is in front of Athena. Only Athena, because of her relationship to Zeus, is worthy of judging a case between two divinities.

This idea of a just Athena who uses her law courts to solve problems for suppliants (even divine ones) has great significance in the real Athens of the fifth century. For as early as possibly the late 460s Athens was already requiring some of her allies to send court cases to Athens. The Phaselis decree (IG I ${ }^{3} 10$ ), mentioned above, is possibly the earliest instance of this process. Although the exact nature of the cases to be tried at Athens is unclear from the inscription, it has been argued that the right to try certain cases there would have been seen as a privilege. ${ }^{73}$ And it is this suggestion that Phaselis would have felt privileged to send certain cases to Athens that is in keeping with the spirit of Eumenides. ${ }^{74}$ Orestes and other allies understand that justice dispensed at Athens under the auspices of Athena is superior. But there is a darker side to such justice and it is found reflected in another decree, passed soon after the production of Eumenides.

The Erythrai decree (IG I ${ }^{3} 14$ ), dated to $453 / 2,{ }^{75}$ has a much different tone from the Phaselis decree. It is in the form of an oath and lists the sanctions imposed upon Erythrai after her revolt from the Delian League. Some of the provisions of the oath run as follows:

- The Erythraians must bring grain to the Panathenaia.

- A democracy must be installed under an Athenian overseer ( $\varepsilon \pi i \sigma \varkappa o \pi \circ \varsigma$ )

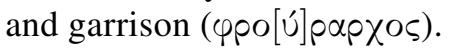

- Officers in the democratic government must take an oath of loyalty to the Athenian people and to her allies.

- Murderers are to be punished by death.

- Any man exiled from Erythrai is automatically exiled from Athens and all allied cities. But no one can be exiled without permission from Athens.

The cases might not be tried in Athens, but the authority behind the punishment is directed by the Athenians. And it is this practice that continues, even made

73. See above, n. 64 for date. For the idea that a trial in the polemarch's court (as is stipulated in the decree for foreigners) was a privilege, cf. de Ste. Croix 1961: 100-101. Fornara 1979 sees Ste. Croix's arguments as "labored" and agrees with Wade-Gery that this inscription is proof of Athenian "judicial hegemony." Also important, as Fornara points out, is the suggestion in line 10 that the regulations for Phaselis are to follow those already agreed upon regarding Chios. This suggests that this decree, which Fornara dates to the mid-fifth century, is part of a chain of such decrees-a trend, if you will.

74. Bradshaw 1991: 123 states in passing, "the Aeschylean trilogy is clearly related to the judicial reforms that made Athens the legal center for trying all homicide cases, indeed, all capital cases involving members of the confederacy." Unfortunately, he does not elaborate on this point.

75. This decree can be dated possibly as early as $455 \mathrm{BC}$, but no later than $452 \mathrm{BC}$. Although he previously argued for a later date, Mattingly 1996: 169 now agrees with the majority opinion that the Erythrai decree cannot be later than 452 BC. 
stricter, in the Miletos decree of $450 / 449\left(\mathrm{IG} \mathrm{I}^{2} .22+\right)^{76}$ and the Chalcis decree of $446 / 5$ (IG I ${ }^{2} 39$ ). In each of these decrees, provisions are made for trying certain court cases in Athens, including murder. And although the Chalcis decree is dated a full decade after the production of Eumenides, the text of the decree actually confirms, not establishes, judicial controls already in place. This decree is dated to around $446 \mathrm{BC}$ following the suppression of a revolt there. The earlier decree to which this one refers most likely came from the $450 \mathrm{~s}^{77}$

As the century wore on and the Delian League was transformed more certainly into the Athenian Empire, the requirement that cases involving large fines, death penalties and exiles continued to be tried in Athens was expanded to include allies such as Samos, Rhegion and Leontini. Meiggs states that it is only "natural" for the Athenians to move court cases to Athens concerning possible threats to her authority after the Peace of Kallias when keeping the League in order became more important than fighting Persians. ${ }^{78}$ This gave the Athenians a measure of control over the activities of those would-be opponents of Athenian domination. ${ }^{79}$ That the Athenians would be emphasizing their "just" and litigious nature in a play dated only a few years prior to the first certain decree of this type should not seem odd. It may have even served as a harbinger of what was to come. ${ }^{80}$

Before Athena establishes the Areopagus court, Apollo promises Orestes to Athena/Athens as a summachos. Athena accepts Orestes as her ally, for all appearances, and establishes a court to try him, a murderer and an exile. ${ }^{81}$ Both Orestes and the Erinyes have agreed to abide by its ruling and the Areopagus will

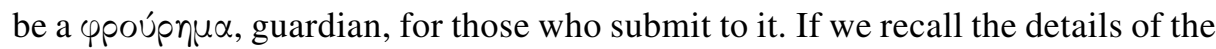
Erythrai decree (IG I $\left.{ }^{3} 14\right)$, a few overlaps appear. Athenian justice, while not direct, is to be enforced on her new allies in Erythrai just as Orestes will subject himself to Athena and her court of Athenians. The Erythraians must swear an oath to the Athenians and the other summachoi, an oath not unlike the one Orestes

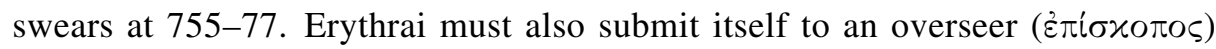

76. Again, Mattingly argues for a date ca. $426 / 5$ BC. Meiggs, Barron and the authors of the $A T L$ all agree on a date around $450 \mathrm{BC}$. Fornara argues for ca. $442 \mathrm{BC}$.

77. That this decree refers back to an earlier one is suggested by references in the decree to

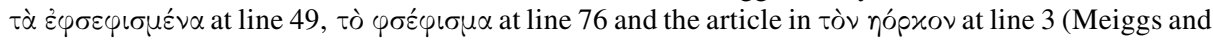
Lewis 1969: 140). Again, as with the other decrees discussed, Mattingly argues for a date ca. 424/5 BC against Gomme, Fornara, Sealy, Meiggs, Woodhead and the authors of ATL, who all agree to a date of ca. 446/5 BC.

78. Meiggs 1972: 221.

79. A number of gains accrued to the Athenians from transferring certain court cases to Athens. First and foremost would be reducing the ability of those with anti-Athenian or anti-democratic sentiments to pursue frivolous lawsuits against pro-Athenian members of an allied community. In this respect, the proxenoi of Athens in these states also would benefit, as de Ste. Croix 1961 suggests. However, those would seem to be the only non-Athenians to benefit from the arrangement.

80. Raaflaub 1998: 20 states that the Athenians and other Greeks were probably fully aware of the conversion of the Delian League into the Athenian Empire in the late 460s. This coincides precisely with the production of Oresteia.

81. Or, tyrannicide. This idea will be addressed more fully below. 


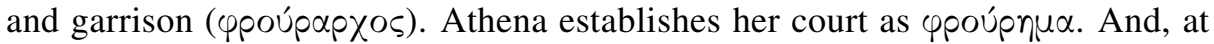

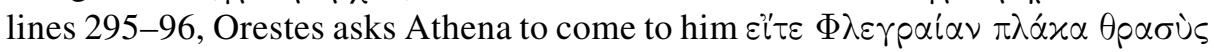

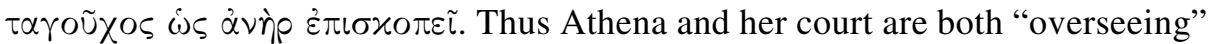
lands and standing guard over them as well. This is just what the Athenians will supply for her summachoi according to the terms of the Erythrai decree.

The process of judicial imperialism that is emphasized by the Phaselis and Erythrai decrees is exactly the type of relationship between allies that is legitimized in Eumenides. Athena in her role as both goddess and city patron can be understood as Athens defending and touting her judicial system to the allies. Athena, by trying Orestes' case in Athens, suggests that it can only be solved there. Only in Athens, Athena's city, can true justice be found.

Recall as well the fact that Apollo himself sanctions and requests the establishment of this court. This is interesting considering the relationship between Athena and Apollo in their patronage of the Delian League. Apollo seems originally to have been patron of the League whose center was on Delos, and the aparche was initially dedicated to him. ${ }^{82}$ Around $454 \mathrm{BC}$, however, the League treasury was transferred to Athens and the aparche was dedicated to Athena instead of Apollo. Shapiro has argued that there was no significant diminution of Apollo's association with the League in the years following the transfer but rather that Athena and Apollo came to have a "reciprocal relationship," sharing the task of protecting the allies. ${ }^{83}$ I would go further by suggesting that Eumenides prefigures the transfer of the treasury, and thus patronage of the League. Apollo, by urging Orestes to have his case tried in Athens, is recognizing the judicial superiority

82. Although direct evidence is lacking, it has always been assumed by scholars that Apollo was patron of the Delian League at its founding. This view has been based primarily on the fact that the League meetings and treasury were based on Delos, an island devoid of people for the most part. Only the shrine to Apollo rested there, thus the treasury would have been under his protection. Also, it seems only logical that there was a precedent for the aparche that would be awarded Athena after 454 BC. If Apollo had not received a similar tithe, uproar over Athens' claim would surely have left a trace. It has also been noted by Barron 1983: 11 that Poseidon was a probable secondary patron, for he was the original patron of the earlier Ionian League (Hdt. 1.141.4; 1.170.1; 6.7) and, as a naval venture, the League would have done well to keep the favor of the sea-god. These various associations are discussed in Smarczyk 1990, the only book-length study of the use of religion as propaganda by the Athenians during the fifth century.

83. Shapiro 1993: 101-13 gives as proof of this a number of vases which show Apollo and Athena flanking Orestes as well as other vases depicting sacrifices to Athena and Apollo. Euben 1990: 80, however, would disagree: "There is external, though inconclusive evidence that the Athenians regarded Apollo as pro-Spartan at precisely the time Athens was turning away from its one-time ally to that ally's foe, Argos. Moreover, Apollo had given bad-some thought traitorousadvice to the Greeks at the approach of the Persian armies in 480 BC. Finally, some Athenians were apparently critical of what they regarded as the meddling of the god in their internal politics." Euben does not list his "external" sources. The fact that Apollo is representing Argos at Athens in Eumenides seems to counter Euben's first statement. Also, the prophecy of Apollo to "trust to your wooden walls" was well enough received by the Athenians-not so traitorous a statement. I find Shapiro's argument for the continued cooperative nature of Apollo and Athena's relationship much more satisfactory especially since the continued cooperation between the two gods would serve as further propaganda for the Athenians. 
of Athena and the democratic institutions embodied in the jury of Athenians. ${ }^{84}$ Not only does the text legitimize Athenian judicial imperialism in Eumenides, but it gives it divine sanction by depicting the first patron of the Delian League as endorsing the transfer of authority. ${ }^{85}$

A claim for Athenian hegemony has been made through a political subtext found in Eumenides. This subtext consists, first, of the "imperial geography" noted above and the military and quasi-inscriptional language of the play. The use

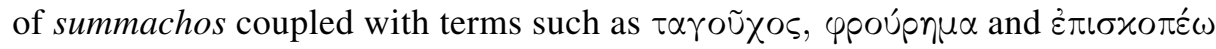
emphasizes the military nature of the alliance to which Athena and Orestes are agreeing. The fact that Orestes, the summachos, is a murderer and exile seeking judgment in an Athenian court points toward the developing Athenian practice of trying allies' cases concerning murder, exile and treason in Athens instead of in their own cities. But is this presented as a positive thing? Is the overall impact of this episode a justification of or a criticism of such an attitude of cultural superiority and its underlying imperial aspirations? If, as I propose, Eumenides provides an overall justification for imperial practices, then we must consider whether the transfer of jurisdiction by an ally to Athens can be understood positively.

As mentioned in the introduction to this article, the suggestion that Eumenides creates and supports a pro-imperialist ideology is not obvious. In fact, the only scholarly attempts to directly address empire as an influence in Aeschylean tragedy have argued for a decidedly anti-imperial stance for the play as well as the trilogy as a whole. Rosenbloom has written what is the most committed argument for an anti-imperialist stance. And it must be admitted that there are a number of more sinister readings available for some of the very passages I have addressed.

The first of these troublesome associations concerns the connection I have made between the language of the play and the Erythrai decree. What seems so appealing in Eumenides, the right to see a difficult case tried in Athenian courts, seems to lose its appeal when compared with the Erythrai decree. Surrendering

84. Sommerstein 1989: 230-34 also points out two moments in the play which seem to support the notion of Athena superceding Apollo. The first is Athena's assertion at 736-38 of her relationship

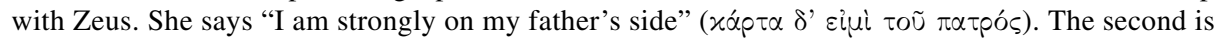
Orestes' farewell address. This address, Sommerstein writes, implies that Apollo has now "ceased to be relevant" and underscores Apollo's unmarked exit from the stage. For a different view on the exit of Apollo, cf. Taplin 1977: 403-407.

85. Euben 1990: 32 writes, "The Athenians, in alliance with a god [Apollo], defined a way of life as well as a physical one; [that] they have charted a moral and political wilderness as well as a physical one." I would amend that statement slightly. It was Athens, in league with Athena. Apollo just helped them get started. There also seems to be a trend that will emerge in Athenian mythography that supports this reading of Apollo's deference to Athena. The most striking instance is Euripides' Ion. Here, the Athenian descent of Ion is repeatedly emphasized by the stress laid on the need to put a descendent of Creusa on the Athenian throne. Also, Athena's appearance at the end of the play emphasizes Ion's autochthonous ancestry over his Apolline. That Athena says Apollo "sent her" in Ion only means that, as in Eumenides, he defers to her authority. 
control over law courts is one of the key steps toward loss of autonomy. It is a sure sign of one state's subjugation to another. Herodotus wrote with regard to the conflict between Epidaurus and Aegina that the Aeginetans were subject to Epidaurus to such an extent that they had to cross to Epidaurus to have their law cases heard (5.83). ${ }^{86}$ Herodotus probably wrote this over twenty years after Eumenides was produced. What his attitude must surely reflect, however, is the process by which Athens converted her allies into subjects and changed the Delian League into an Empire. Extradition was seen as a projection of imperial power.

This question on the benefits and perceptions of transferring jurisdiction is compounded when considered in light of another potentially problematic association which I passed over earlier: a possibly veiled reference to cleruchies

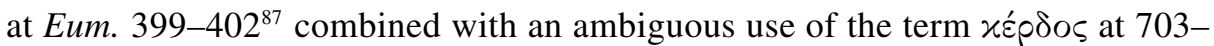
706. Analysis of each of these passages together can lead to a decidedly antiimperialism interpretation of the play as a whole. ${ }^{88}$ How, then, can I argue that this text participates in an ideology that supports practices which were clearly considered tyrannical by Athens' allies?

The idea that there is a possible reference to cleruchies at 399-402 and 703706 is interesting, but difficult to address since we know so very little about the nature and number of cleruchies in the fifth century. ${ }^{89}$ The only certain fifthcentury cleruchies we know of are those on Naxos, Andros and Euboea (ca. 450 BC), and Mytilene (ca. 427 BC). Cleruchies were sent out from Athens as both a form of population control within Athens and as a way to garrison restless allies with Athenians invested in the continuation of the empire. This process seems to have begun shortly after the halfway point of the fifth century and continued on until the Athenian defeat in the Peloponnesian War. It is quite certain that the allies despised the practice since a main condition of the Second League was that no cleruchies be sent out by Athens..$^{90}$ But whether or not the allies already hated the practice in $458 \mathrm{BC}$ is questionable. Rather, within the context of the play, just as with the concept of Athenian courts, there is only the justification

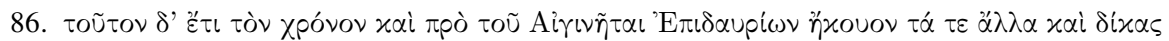

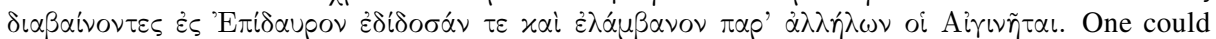
think of the United States' reluctance to submit to the World Court or China's attempts to hold extra-territorial judicial control in Singapore. There seems to be something absolutely "submissive" in allowing one nation to provide "justice" for another. It basically means admitting one's own inability to do so or the superior ability of another to do it for you.

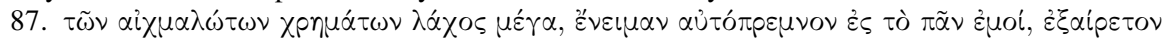

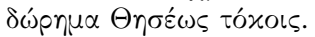

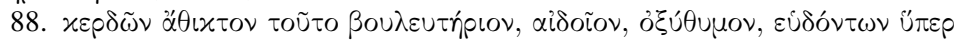

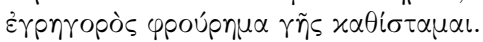

89. Cf. Figueira 1991: 40-56 for the definition of a cleruchy and how it differs from a regular colony.

90. Meiggs 1972: 260-62. In fact, the decree (IG II ${ }^{2} 43$ lines 25-31 and 35-46) bans all types of Athenian ownership in allied territories. 
for what would become a standard practice after $450 \mathrm{BC} .{ }^{91}$ The establishment of cleruchies perhaps even contributed to a growing imperialist mentality. As

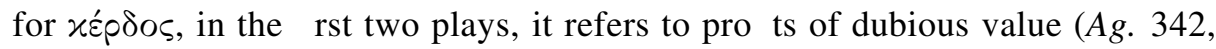
547; Cho. 825). Within the context of Eumenides, the term moves from being ambiguous $(541,704)$ to referring to "true and lasting benefits." 92 At this stage, the reference to cleruchies, if it is a reference at all, can only be understood as a validation of a subsequent practice and not likely to incur the wrath of allies. ${ }^{93}$ Allies, like Orestes, should submit willingly to Athenian jurisdiction as well as to her benevolent controls.

Justice, as it is invoked in both Agamemnon and Choephoroi, is retributive and familial. ${ }^{94}$ In Eumenides, justice is expressed by the non-violent verdict of the Athenian jury-a verdict that is decisive and unambiguously fair. ${ }^{95}$ Agamemnon kills Iphigeneia, so Clytemnestra kills him as punishment. Atreus kills Aegisthus' brothers, and so he participates in Agamemnon's murder out of desire for revenge. Orestes kills both Clytemnestra and Aegisthus as retribution for Agamemnon's murder. This cycle of justice would have continued with Orestes' death (by his own hand, perhaps) if Athena had not stepped in to stop it. ${ }^{96}$ This justice is indeed justified if we understand Orestes, as the audience may indeed have understood him, as a tyrannicide. ${ }^{97}$

91. This would be in keeping with the practice the Athenians had of creating mythical precedents as justification for colonization, especially myths about the Strymon River region. Cf. Parker 1983: 43.

92. Sommerstein 1989: 271.

93. If allies were even in the audience in $458 \mathrm{BC}$.

94. Justice in Agamemnon is couched frequently in the technical terminology of the courts but invariably finds expression in physical violence and revenge. Cf. Lloyd-Jones 1970 on line 40; Podlecki 1989: 40-45; Sommerstein 1989: 19.

95. Sommerstein 1989: 222 suggests that we understand the jury decision at Eum. 711-53 as a mirror of the deliberation scene at $A g$. 1346ff. in which the chorus puts forth a number of views on how to react to Clytemnestra's actions but, in the end, fail to act. Athena, as a foil to Clytemnestra, who understands the indecision of the chorus as making the debate moot, takes indecision (the tie) and makes it effective decision (tie goes to the defendant).

96. This statement, while agreed upon by the majority of scholars, is contested by Cohen 1986. Cohen argues that the emphasis of Aeschylus on the suffering of innocents such as Iphigeneia should lead one to the conclusion that Zeus' justice is tyrannical and immoral and based on force and fear. That Athena invokes fear of the Erinyes as part of her "new order" and must threaten them in order to get them to cooperate only confirms Cohen's belief. Cohen, however, has missed two significant points. First, the justice portrayed in Eumenides is a progression away from the forms of justice found in Agamemnon and Choephoroi. The justice Athena establishes is not based on retribution and it silences the cycle of murder perpetuated by such a concept of right and wrong. Athena's new justice also brings to light the very contradictions in such a system. In a retributive system, one man's right is always another's wrong. The justice embodied in the court of the Areopagus puts a stop to the cycle. The second point Cohen misses relates to fear. He emphasizes the fear that the Erinyes will supply as part of Athens' new order. This fear, he argues, makes the new justice just as tyrannical as the old. But fear does not necessarily mean that fair, impartial justice cannot be present. The Erinyes represent the fear of wrongdoing that should act as a deterrent against harming others.

97. On Orestes as a tyrannicide, cf. Daube 1939: 46-47. 
This progression from retribution to court-enforced justice follows along the path of Rosenbloom's ideology of freedom. For it is through the use and abuse of the concept of justice that the Argive people are enslaved (by Aegisthus the tyrant) and then freed (by Orestes the tyrant-slayer). But the conclusion is not, as Rosenbloom would have it, that Orestes must now become the tyrant in Aegisthus' place and suffer collapse. ${ }^{98}$ For, Orestes does not, like his predecessor, become the tyrant in turn and then suffer subversion. Rather, Athena comes on stage to prevent the very continuation of this cycle, and employs her Athenian jury as a replacement. Athena guarantees freedom by providing a proper form of justice to support it and by turning Orestes, not into an Eastern despot, but into an ally of Athens and one who submits openly to democratic judgments. ${ }^{99}$

The same fundamental principle applies to Peitho since it is a necessary part of the new justice. Whereas Peitho is the child of Ate in Agamemnon, ${ }^{100}$ she is a necessary element in Athena's new justice in Eumenides. ${ }^{101}$ And whereas Peitho leads to the destruction of Troy, Agamemnon and Aegisthus in the earlier plays of the Oresteia, it leads to the salvation of Orestes and of Athens in Eumenides. For Peitho, according to Buxton's assessment of it in tragedy, is linked to nomos and dike. It is a civilizing force set opposite bia and tyranny. ${ }^{102}$ But does this mean that any negative connotation connected with Peitho has been erased? It is still a tool of power. Athena's superior position vis à vis the Erinyes is affirmed through their submission to her persuasive efforts just as Agamemnon's surrender to Clytemnestra's seals his doom. ${ }^{103}$

Agamemnon's submission to persuasion signals the superiority of Clytemnestra (940-43). Both Clytemnestra and Agamemnon perceive her persuasion in terms of a battle ( $\mu \alpha \times \chi \eta, \delta \tilde{\eta} \rho \iota \varsigma)$ that is to be won or lost. Agamemnon's submission

98. Rosenbloom 1995: 94 writes, "Freedom is fundamental but insufficient in the absence of justice; domination either falls or is threatened with collapse."

99. Whether her verdict is right or wrong is really irrelevant. In a sense, each party in the trial (and in the entire retributive cycle) is right in some way. What is relevant, however, is the suppression of the violence inherent in this cycle. It can be said that right or wrong in most cases are relative labels. The court removes the authority from the individual to decide and puts the good of the community over the good of the individual by disallowing ambiguity. Here is another fine message to send a subject-ally.

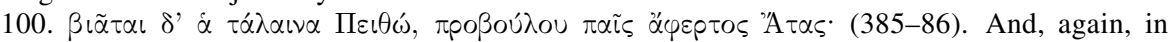

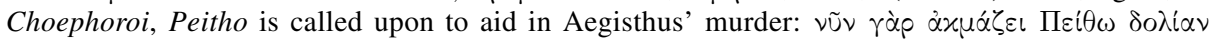
$\xi \cup \gamma \varkappa \alpha \tau \alpha \beta \tilde{\eta} \nu \alpha \iota$ (726). Buxton 1982: 106-108 accounts for Peitho being bound to such injustices by claiming that these are instances of false Peitho. Clytemnestra's persuasion of Agamemnon is "deception masquerading as Peitho." Peitho itself, according to Buxton, is really a cure or remedy. That this healing power of Peitho is not present in either $\mathrm{Ag}$. or Cho. emphasizes the false nature of the Peitho involved.

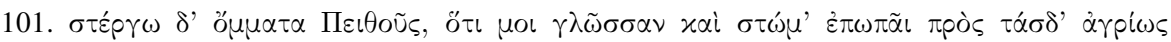

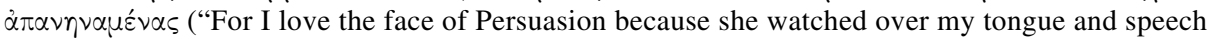
toward those goddesses refusing vehemently," 970-72).

102. Buxton 1982: 58-65.

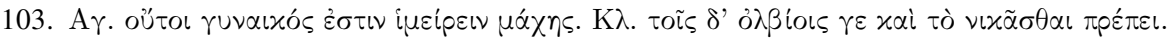

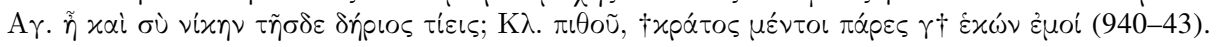


signals a victory ( $\nu i \chi \eta)$ for Clytemnestra, and Agamemnon, in turn, becomes the

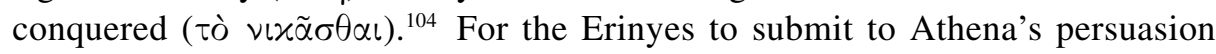
likewise signals their own submission to her authority. She becomes the guarantor of their powers and they become residents who will help protect Athena's city from any external or internal harm.

This submission, however, is positive within the context of the play. Twice Athena appeals to Peitho $(794,885-91)$ and it is persuasion to which the Erinyes, in the end, submit although a veiled threat is leveled by Athena. At Eum. 824-29, Athena tells the Erinyes that they have not been dishonored. She then says:

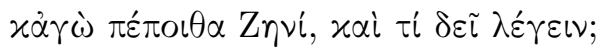

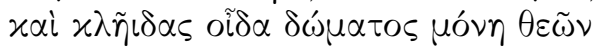

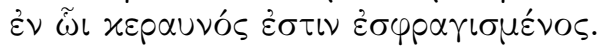

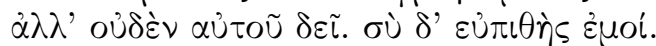

$$
\begin{aligned}
& \text { Eum. 826-29 }
\end{aligned}
$$

I too trust in Zeus, why is it necessary to say it? And I alone of the gods know where the keys to the halls are in which the thunderbolt is kept safe. But no need of that; be persuaded by me....

It is interesting to note that numerous scholars, including Winnington-Ingram and Lloyd-Jones practically ignore the final appeal of Athena and credit the "threat" (or the will of Zeus embodied in it) with changing the Erinyes' decision. ${ }^{105}$ But, as Sommerstein points out, regardless of the threat, the thunderbolt stays hidden, unlike in Agamemnon where it is not. ${ }^{106}$ The violence inherent in the thunderbolt is appropriate to the vendetta-like justice of Agamemnon. In Eumenides, the thunderbolt becomes muted and unnecessary in light of the power of persuasion and the type of justice connected with it. In the end, it is justice ( $\delta(x \alpha i \omega \varsigma)$ that persuades the Erinyes $(888,891)$. Why mention the thunderbolt at all? In order to point out how far justice has progressed. The option of violence still exists, but Athena and her Athenians have no need of it since they have their courts and persuasion. ${ }^{107}$

It is the establishment of the court and the submission by all parties in Eumenides to the authority of that court that ultimately undermines any antiimperialism reading of the trilogy. All parties, be they gods, allies, metics or

104. Buxton 1982 suggests that it is this dynamic emphasizing power and conquest that overrides and subordinates Peitho. It is this dynamic that drives Agamemnon to concede to Clytemnestra and also diminishes the healing power of persuasion itself.

105. Winnington-Ingram 1983: 101 states in relation to Athena's threat, "Tactfully, yet firmly, she reminds the Furies of the thunderbolt of Zeus — which had already been employed against recalcitrant divinities of an older generation. The will of Zeus for the evolution of human society is not to be frustrated." The threat, he surmises, is to remind the Erinyes that under the code of "justice" to which Orestes and Apollo subscribed, Orestes was not to blame since his actions were also the will of Zeus. The will of Zeus is absolute. Cf. Lloyd-Jones 1956: 64.

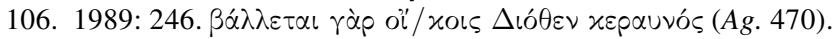

107. On the court as the embodiment of a new "democratic" justice, cf. Daube 1939: 54-63. 
Athenians, agree to the jurisdiction and wisdom of the court and its new kind of justice. Not only does this fact undermine an anti-imperialism reading, but it ultimately supports Athenian judicial imperialism in the beginning in the 450s and following. The idea of the courts becomes so intertwined with the concept of democracy and Athenian identity that it cannot be understood any other way.

During the course of the fifth century, as the democracy became more radical, the importance of courts and juries grew. This reason is somewhat obvious. The first step toward democracy, typically attributed to Solon in 594 BC, was rooted in the notion of the Heliaia, a people's court, to which the common people could appeal the decisions of aristocratic magistrates. ${ }^{108}$ The proliferation of courts, however, did not begin in earnest until the 460s and 450s. We do not know the earliest date for the variety of juries that came into being during the Classical period. We do know, however, that pay for jurors was introduced by Pericles in the middle of the century ${ }^{109}$ and a number of buildings that were used to house law courts or serve as repositories of laws like the Stoa Basileos, Stoa Poikile, the Metoicheion, even the Odeion, were all built or rebuilt between 460 and 450 BC. ${ }^{110}$ The law courts and juries were becoming a regular, and important, part of democratic citizen life.

Eumenides contributes to this identification of Athens with courts, thereby strengthening the connection between Athens and democracy. Aeschylus himself emphasizes that his court, the one Athena establishes, is the Areopagus. But this in no way diminishes the intimate connection between courts and Athenian democracy. Rather, Aeschylus may have chosen the Areopagus not necessarily because of its connection to the recent reforms of Ephialtes, but more so because of the very antiquity of that specific court. It was the oldest court in Athens, dating back to the seventh century, and the homicide law was the oldest law, dating back, so the Athenians thought, to Drakon. ${ }^{111}$ By pushing the foundations of the first law court back to the heroic age, Aeschylus underscores the tradition of such judicial practices in Athens, thus embedding the concept that much more firmly within the Athenian collective democratic consciousness.

Aeschylus also is not the only artist in Athens at that time to emphasize the collective power of the Athenian demos. As Mills puts it, "in its emphasis

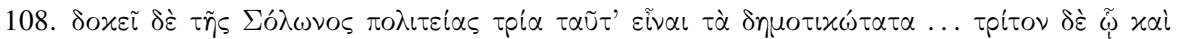

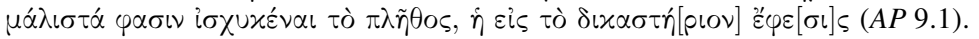

109. Pay for jurors: Aristotle Politics 1274a 8-9, AP 27.3 and Plutarch Per. 9.3-5. That pay for jurors was instituted sometime around 450 implies that juries themselves were around before then.

110. The Stoa Poikile and Stoa Basileos were both built sometime around 460 BC. For the Poikile cf. Shear 1984: esp. 13-18 and Camp 1986: 64-72 and figs. 40-44. For the Basileos, cf. Camp 1986: 100-105 and figs. 75-77. For the Odeion, cf. Boegehold 1995: 178, 1967: 111-20; it is not known whether the Odeion was used as a court prior to $422 \mathrm{BC}$. For the Metoicheion, cf. Boegehold 1995: 177-78. The Metoicheion may have been the building in which the Heliaia judged from the 440 s to the 420 s.

111. Aristotle Politics 8.125 . 
on the collective, the Eumenides is unusual among tragedies in being closer to the conventions of much public art..."112 The silent Athenian jurors reflect the same collective identity as the fighters depicted on the Stoa Poikile and Theseion both in the Amazonomachies and the Marathon painting. ${ }^{113}$ In addition to this emphasis on collectivity in public art, justice itself becomes a topic of paintings. The representations of myths such as that of Ajax Locrus find new life in Athens both in the Stoa Poikile and on the tragic stage. But the myth is altered to contain a possible trial scene presided over (indirectly) by Athena. ${ }^{114}$

\section{CONCLUSION}

Aeschylus and his Eumenides are part of a larger matrix of thought that praised and promoted certain political institutions among Athenians and other Greeks. The courts were a true manifestation of the power of the demos. This was "a collective illusion closely tied to a new nationalism, which argued the coherence and superiority of [Athenian] social and political order, [Athenian], civilization and [Athenian] science." 115 And nationalistic is close to what one might call the artistic output of the post-Persian War years. As I have argued, this new nationalism is tied together and contextualized by geography:

Just as none of us is outside or beyond geography, none of us is completely free of the struggle over geography. That struggle is complex and interesting because it is not only about soldiers and cannons, but also about ideas, about forms, about images and imaginings. ${ }^{116}$

112. Mills 1997: 56.

113. Mills 1997: 56-78 discusses in some detail the idealized image of the Eumenides and its role as a predecessor to the epitaphioi. These funeral speeches participated directly in shaping the national identity of Athenians and in revealing how the Athenians wished others to perceive them. For a full discussion of the role of epitaphioi in Athenian civic ideology, cf. Loraux 1986.

114. The paintings in the Stoa Poikile are, like the structure itself, dated roughly to $460 \mathrm{BC}$. The painting in question is an Iliupersis painting and is peculiar in that its focal point is the figure of Locrian Ajax with his hand on an altar as if swearing an oath (Pausanias 1.15.3; and for Polygnotus' other version of the Iliupersis in the Cnidian Lesche at Delphi, 10.31.2). Fragments of a play, Ajax Locrus by Sophocles, in which Lesser Ajax stands trial for his crime at Troy, are also dated by some, though on admittedly very little evidence, to sometime prior to 460 BC. Cf. Webster 1969: 202; Zielinsky 1925: esp. 37-43. This would situate both within the same time frame as Aeschylus' Eumenides. Mills does not consider Sophocles' Ajax Locrus in her statement on the unusual nature of the collective nature of Eumenides. This is probably because the play is so fragmentary and because the possibility of a trial taking place there is not certain. It is my own interpretation of the extant fragments that a trial is being represented. A striking element of the fragments that leads me to this conclusion is the occurrence of legal language, most notably a conjectured $\alpha \pi \sigma \psi \eta \varphi i \zeta \varepsilon \sigma \theta \alpha \iota(\mathrm{P}$. Oxy. 3151, 5; line 11 = F10f. 11 Radt [TrGF vol. 4, p. 108]) which otherwise occurs nowhere in extant poetry. If a trial does take place within the play, it would suggest striking similarities with the visual representations of the myth.

115. Godlewska 1994: 35 . She is speaking of French nationalism, but the terms apply to fifthcentury Athens as much as to Revolutionary and Napoleonic France.

116. E. Saïd 1993: 7. 
Thus before the court can be established, before the trial can take place, before Peitho can sway the Erinyes, the imaginary geographic landscape within which they will function must be established.

Like the representation of justice, the geography of Aeschylus' text is neither random nor unintentional. It represents a fascination on the part of the Athenians with the world outside, the unknown. But it also participates in a dynamic always present to geography, namely the drive for knowledge that is both premised upon and leads to the acquisition of power. While Aeschylus' intentions with geography may have been only to feed curiosity or to tap into current events, the references, coupled with an enthusiastic patriotism and a desire to show the greatness of justice in Athens, give rise to and feed a powerful imperialist ideology.

The courts are explicitly linked within Eumenides to geography. Athena establishes her court as a defense and salvation such as no other can claim among either the Scythians or the Peloponnese. She establishes her court to administer justice specifically to her allies, not Athenians. Thus to ignore the importance of the relationship between geography and Empire within the play is to ignore the relationship between knowledge and power. To ignore the ever-present specter of Empire in the life of Athens is to ignore tragedy's full context. The administration of justice too was a part of this context. The courts were used by the Athenians to justify both their cultural and military superiority. ${ }^{117}$ Justice became a tool of Empire just as geography always already is one.

Whether or not Aeschylus consciously intended his combination of geography and justice in the Oresteia to contribute to an imperialist ideology, his trilogy certainly demonstrates the same concerns, justice and geography, that were shared by other Athenian artists and citizens of the period. The result is a work infused with an imperial ideology that is inextricably bound to the ideals of freedom and democracy. For this reason alone, perhaps, scholars have been reluctant to see Empire lurking in the shadows of Aeschylus' plays. Perhaps neither Aeschylus himself nor his audience was fully aware at that time of the link between freedom for themselves and tyranny over others. Or, perhaps, modern scholars don't wish to see Aeschylus sullied by association with the mechanisms of imperial power. Sullied or not, the mechanisms are present. Geography plus Justice in Aeschylus equals Empire.

The George Washington University rfutokennedy@gmail.com

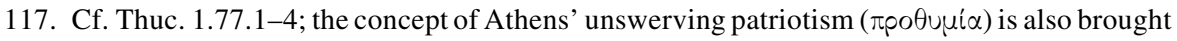
up twice in this same speech $(1.74 .2,1.75 .1)$. 


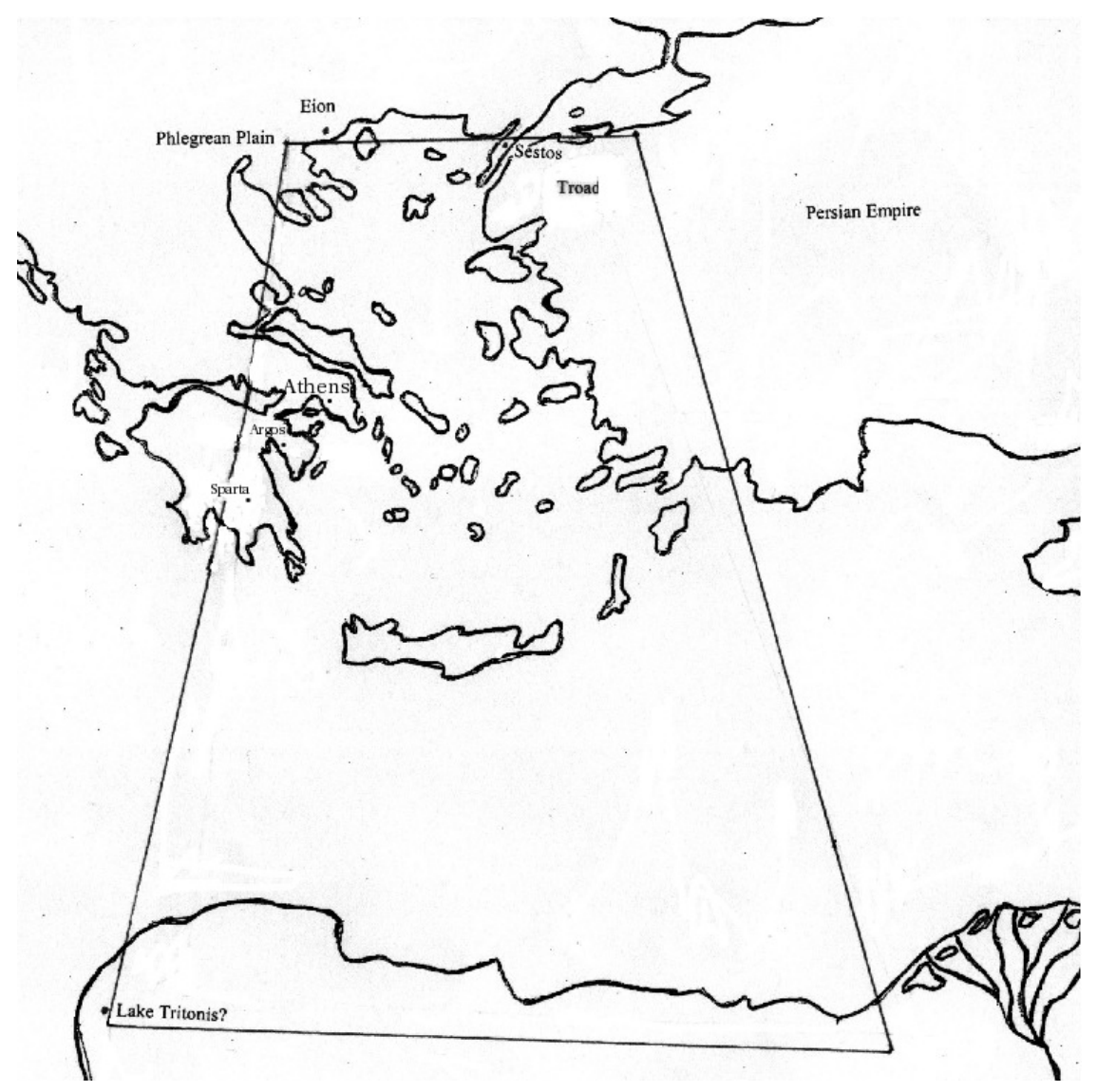

Figure 1: Map of Aegean and Egypt. The enclosed space represents the region defined by Aeschylus' Eumenides.

\section{BIBLIOGRAPHY}

Anderson, G. 2003. The Athenian Experiment: Building an Imagined Community in Ancient Attica, 508-490 BC. Ann Arbor.

Badian, E. 1993. From Plataea to Potidaea. Baltimore.

Barron, J. P. 1964. "Religious Propaganda of the Delian League." JHS 84: 35-48. . 1983. "The Fifth-Century Horoi of Aigina." JHS 72: 1-11.

Boedeker, D. 1998. " "Presenting the Past in Fifth-Century Athens." In D. Boedeker and K.

Raaflaub, eds., Democracy, Empire and the Arts in Fifth-Century Athens, 185-202.

Cambridge, Mass.

Boegehold, A.1967. "Philokleon's Court." Hesperia 36: 111-20.

. 1995. The Law Courts at Athens. Athens.

Bowie, A. M. 1993. "Religion and Politics in Aeschylus' Oresteia." CQ 43: 10-31. 
Bradshaw, D. J. 1991. "The Aias Myth and the Polis." In D. Pozzi and J. Wickersham, eds., Myth and the Polis, 99-125. Ithaca.

Braun, M. 1998. Die Eumeniden des Aischylos und der Areopag. Tübingen.

Buxton, R. 1982. Persuasion in Greek Tragedy: A Study of Peitho. Cambridge.

Calder, W. M. 1981. "The Anti-Periklean Intent of Aeschylus' Eumenides." In E. G. von Schmidt, ed., Aischylos und Pindar, 220-23. Berlin.

Camp, J. M. 1986. The Athenian Agora: Excavations in the Heart of Classical Athens. London.

Cartledge, P. 1998. "The Machismo of the Athenian Empire-Or the Reign of the Phaulus?" In L. Foxhall and J. Salmon, eds. When Men Were Men: Masculinity, Power and Identity in Classical Antiquity 54-67. New York.

Castriota, D. 1992. Myth, Ethos and Actuality: Official Art in Fifth-Century BC Athens. Madison.

Cohen, D. 1986. "The Theodicy of Aeschylus: Justice and Tyranny in the Oresteia." G\&R 33: 129-40.

Cole, J. 1977. "The Oresteia and Cimon.” HSCP 81: 99-111.

Conacher, D. J. 1987. Aeschylus' Oresteia: A Literary Commentary. Toronto.

Connor, W. R. 1993. "Theseus and his City." In P. Hellström and B. Alroth, eds., Religion and Power in the Ancient Greek World: Proceedings of the Uppsala Symposium, 115-20. Stockholm.

- 1994. "The Politics of Athenian Identity." In A. Boegehold and A. Scafuro, eds., Athenian Identity and Civic Ideology, 34-44. Baltimore.

Daube, B. 1939. Zu den Rechtsproblemen in Aischylos' Agamemnon. Zürich.

Denniston, J. D., and D. L. Page, eds. 1957. Aeschylus, Agamemnon. Oxford.

Dodds, E. R. 1973. The Ancient Concept of Progress and Other Essays. Oxford.

Dover, K. J. 1957. "The Political Aspects of Aeschylus' Eumenides." JHS 77: 230-37.

Euben, J. P. 1990. The Tragedy of Greek Political Theory: The Road Not Taken. Princeton.

Figueira, T. 1991. Athens and Aigina in the Age of Imperial Colonization. Baltimore.

Fornara, C. 1979. "The Phaselis Decree." CQ 29: 49-52.

Gagarin, M. 1976. Aeschylean Drama. Berkeley.

Garland, R. 1992. Introducing New Gods: The Politics of Athenian Religion. Ithaca.

Godlewska, A. 1994. "Napoleon's Geographers (1797-1815): Imperialists and Soldiers of Modernity." In A. Godlewska and N. Smith, eds: 31-53.

Godlewska, A., and N. Smith, eds. 1994. Geography and Empire. Oxford.

Goldhill, S. 1990. "The Great Dionysia and Civic Ideology." In J. J. Winkler and F. I. Zeitlin, eds., Nothing to Do with Dionysos? Athenian Drama in its Social Context, 97-129. Princeton.

- 1992. Aeschylus. The Oresteia. Cambridge.

- 2000a. "Civic Ideology and the Problem of Difference: The Politics of Aeschylean Tragedy, Once Again." JHS 120: 34-56.

- 2000b. "Greek Drama and Political Theory." In C. Rowe and M. Schofield, eds., The Cambridge History of Greek and Roman Political Thought, 60-88. Cambridge.

Griffin, J. 1998. "The Social Function of Attic Tragedy." CQ 48: 39-61.

Griffith, M. 1977. The Authenticity of Prometheus Bound. Cambridge.

_ 1995. "Brilliant Dynasts: Power and Politics in the Oresteia." ClAnt 14: 62129.

Herington, C. J. 1970. The Author of the Prometheus Bound. Austin. 
. 1988. “No-Man's-Land of Dark and Light.” In H. Bloom, ed., Aeschylus's the Oresteia, 121-54. New York.

Hornblower, S. 1991. A Commentary on Thucydides. Vol. 1, Books I-III. Oxford.

Lebeck, A. 1971. The Oresteia: A Study in Language and Structure. Cambridge.

Lloyd-Jones, H. 1956. "Zeus in Aeschylus." JHS 76: 55-67.

— 1970. Agamemnon. A Translation with Commentary. New Jersey.

_ 1971. The Justice of Zeus. Berkeley.

. 1983. "The Guilt of Agamemnon.” In E. Segal, ed., Oxford Readings in Greek Tragedy, 55-72. Oxford.

Loraux, N. 1986. The Invention of Athens. Trans. A. Sheridan. Cambridge, Mass.

MacDowell, D. 1978. The Law in Classical Athens. Ithaca.

Macleod, C. W. 1983. "Politics and the Oresteia." In C. W. Macleod, Collected Essays, 20-40. Oxford.

Mattingly, H. 1996. The Athenian Empire Restored. Ann Arbor.

Meier, C. 1990. The Greek Discovery of Politics. Trans. D. McLintock. Cambridge, Mass.

1993. The Political Art of Tragedy. Trans. A. Webber. Cambridge, Mass.

Meiggs, R. 1972. The Athenian Empire. Oxford.

Meiggs, R., and D. Lewis, eds. 1969. A Selection of Greek Historical Inscriptions to the End of the Fifth Century B.C. Oxford.

Melchinger, S. 1979. Die Welt als Tragödie. Vol. 1. Munich.

Meritt, B. 1936. "Praise of the Sigeians." Hesperia 5: 360-61.

Mills, S. 1997. Theseus, Tragedy and the Athenian Empire. Oxford.

Nicolet, C. 1991. Space, Geography and Politics in the Early Roman Empire. Ann Arbor.

Papadopoulou, T. 2001. "Representations of Athena in Greek Tragedy." In S. Deacy and A. Villing, eds., Athena in the Classical World, 293-310. Leiden.

Parker, R. 1983. Miasma: Pollution and Purification in Early Greek Religion. Oxford.

— . 1994. "Athenian Religion Abroad.” In R. Osborne and S. Hornblower, eds., Ritual, Finance and Politics, 339-46. Oxford.

. 1996. Athenian Religion: A History. Oxford.

Pelling, C. 2000. Literary Texts and the Greek Historian. Oxford.

Podlecki, A. J. 1973. The Political Background of Aeschylean Tragedy. Oxford.

— ed. 1989. Eumenides / Aeschylus. Warminster.

Quincey, J. H. 1964. "Orestes and the Argive Alliance." CQ 14: 190-206.

Raaflaub, K. 1990. "Contemporary Perception of Democracy in Fifth-Century Athens." In W. R. Connor et al., eds., Aspects of Athenian Democracy, 33-70. Copenhagen.

- 1994. "Democracy, Power and Imperialism in Fifth-Century Athens." In P. Euben, J. R. Wallach, and J. Ober, eds., Athenian Political Thought and the Reconstruction of American Democracy, 103-46. Ithaca.

- 1998. "The Transformation of Athens in the Fifth Century." In D. Boedeker and K. Raaflaub, eds., Democracy, Empire and the Arts in Fifth-Century Athens, 185-202. Cambridge, Mass.

Raubitschek, A. 1973. "The Speech of the Athenians at Sparta." In P. Stadter, ed., The Speeches in Thucydides, 32-48. Chapel Hill.

Rawlings, H. R. 1977. "Thucydides on the Purpose of the Delian League." Phoenix 31: $1-8$.

Rehm, R. 2002. The Play of Space: Spatial Transformation in Greek Tragedy. Princeton. Rhodes, P. J. 1981. A Commentary on Aristotle's Athenaion Politeia. Oxford. 
Robertson, N. 1980. "The True Nature of the Delian League." AJAH 5: 64-133.

Romm, J. 1992. The Edges of the Earth in Ancient Thought. Princeton.

Rose, P. 1992. Sons of Gods, Children of Earth: Ideology and Literary Form in Ancient Greece. Ithaca.

— 2003. “Aeschylus' Geographic Imagination.” APA Annual Meeting.

Rosenbloom, D. 1995. "Myth, History and Hegemony in Aeschylus." In B. Goff, ed., History, Tragedy, Theory, 91-130. Austin.

Saïd, E. 1993. Culture and Imperialism. New York.

Saïd, S. 1985. Sophiste et tyran ou le problème du Prométhée enchaîné. Paris.

- 1998. "Tragedy and Politics." In D. Boedeker and K. Raaflaub, eds., Democracy, Empire and the Arts in Fifth-Century Athens, 275-95. Cambridge, Mass.

Seaford, R. 1995. "Historicizing Tragic Ambivalence: The Vote of Athena." In B. Goff, ed., History, Tragedy, Theory, 202-21. Austin.

Shapiro, H. A. 1993. "Athena, Apollo, and the Religious Propaganda of the Athenian Empire." In P. Hellström and B. Alroth, eds., Religion and Power in the Ancient Greek World: Proceedings of the Uppsala Symposium, 101-14. Stockholm.

_ 1996. "Democracy and Imperialism: The Panathenaia in the Age of Perikles." In J. Neils, ed., Worshipping Athena: Panathenaia and Parthenon, 215-28. Madison.

Shear, T. L., Jr. 1984. “The Athenian Agora: Excavations of 1980-1982." Hesperia 53: 13-18.

Simon, E. 1996. “Theseus and Athenian Festivals.” In J. Neils, ed., Worshipping Athena: Panathenaia and Parthenon, 9-26. Madison.

Smarczyk, B. 1990. Untersuchungen zur Religionspolitik und politischen Propaganda Athens im Delisch-Attischen Seebund. Munich.

Sommerstein, A. 1996. Aeschylean Tragedy. Bari.

. ed. 1989. Aeschylus: Eumenides. Cambridge.

Ste. Croix, G.E. M. de. 1961. "Notes on Jurisdiction in the Athenian Empire I." $C Q$ 11: 94-112.

Taplin, O. 1977. The Stagecraft of Aeschylus. Oxford.

Walker, H. 1995. Theseus and Athens. New York.

Webster, T. B. L. 1969. An Introduction to Sophocles. London.

West, M. 1990. Studies in Aeschylus. Stuttgart.

White, S. 2000. "Intimations of Theodicy in Prometheus Bound." JHS 121: 107-40.

Winnington-Ingram, R. P. 1983. "Clytemnestra and the Vote of Athena." In E. Segal, ed., Oxford Readings in Greek Tragedy, 84-103. Oxford.

Zeitlin, F. 1986. "Thebes: Theater of Self and Society in Athenian Drama." In J. P. Euben, ed., Greek Tragedy and Political Theory, 101-41. Berkeley.

— 1988. "The Dynamics of Misogyny: Myth and Mythmaking in the Oresteia." In H. Bloom, ed., Aeschylus's the Oresteia, 47-72. New York.

Zielinsky, T. 1925. "De Aiacis Locrensis Fabula Sophoclea." Eos: 37-43. 
Reproduced with permission of the copyright owner. Further reproduction prohibited without permission. 